\title{
Soudní kontrola excesivních úroků z prodlení
}

\section{Judicial Review of Excessive Late Payment Interest}

\author{
Dominik Skočovský*
}

\begin{abstract}
Abstrakt
Tento článek se zabývá problematikon excesivnich smluvnich úrokù z.prodleni. Autor nejprve uvažuje, jakými nástroji může soud excesivni smluvni úroky z prodleni żmírnit. Tyto nástroje následně rozděluje do dvou kategorii - nástroju smèrujicich na obsah ujednáni a nástroju smérujicićch na kontrolu primèrérosti výš nároku. Následné článek analyzuje možnost použiti uva žovaných nástroju na excesivni smluvni úroky z.prodleni. Text za využití historické, žcásti zabranični, ale predevšm funkéni komparace poukazuje na podobnost institutu smluvni pokuty (sjednané ve formě odpovidajici úrokuim z.prodleni) a smluvniho úroku z prodlení. Zatímco však neprimèreně vysoká smluvni pokuta podlébá moderaci podle \} 2 0 5 1 OZ, u neprimèrenè vysokého smluvníbo úroku z, prodleni podobný nástroj absentuje. V textu je proto posléze podrobnè argumentován závèr o hodnotovém rozporu spočivajicím v odlišém zacházeni se smluvni pokutou sjednanou ve formě odpovidajici úrokìm z.prodleni a smluvnim úroku zprodleni, který mùze plnit téže funkece. Právě hodnotovým rozporem je tak v textu odiovodñován závèr o mezerére v zákoně,

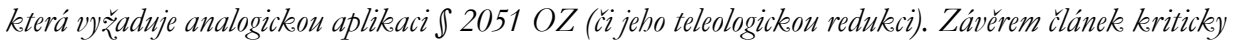

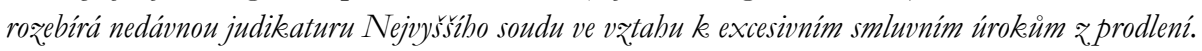

\section{Klíčová slova}

Smluvni urok zprodleni; smluvni pokuta; moderačni právo soudu; excesivni nárok; neplatnost smluvního ujednáni; dobré mravy.

\section{Abstract}

This article deals with the issue of excessive contractual late payment interest. The author first takes into consideration the possible instruments the courts can use to reduce the excessive contractual late payment interest. These instruments are subsequently divided into two categories - those that aim at the content of the agreement and those aiming at the control of the proportionality of the amount of the claim. Further, the possibility of the use of the contemplated instruments for the excessive contractual late payment interest is analyzed. Using historical, partly foreign, but foremost functional comparation method, the text shows the similarities of the institutes of contractual penalty (concluded in a form corresponding with the contractual late payment interest) and contractual late payment interest. While the judge has the power to reduce disproportionately bigh contractual penalty according to $\int 2051$ of the Civil Code, such instrument lacks with regards to the excessive contractual late payment interest. Hence, a conclusion about a value conflict is being further argued in detail. The conflict lies in a different treatment of contractual penalty in form corresponding with the late payment interest and the contractual late payment interest which can serve the same purpose. The value conflict

* JUDr. Dominik Skočovský, doktorand, Katedra obchodního práva, Právnická fakulta, Masarykova univerzita, Brno / Ph.D. student, Department of Commercial Law, Faculty of Law, Masaryk University, Brno, Czech Republic / E-mail: 434130@mail.muni.cz 
is the basis for the conclusion about a legal gap which requires an analogous application of $\int 2051$ of the Civil Code (or its teleological reduction). Last of all the text critically examines the latest practice of the Supreme Court related to the excessive contractual late payment interest.

\section{Keywords}

Contractual Late Payment Interest; Contractual Penalty; Court's Power to Reduce; Excessive Claim; Invalidity of Contractual Provis.

\section{Úvod}

Před účinností zákona č. 89/2012 Sb., občanského zákoníku (dále jen „OZ“) byl konstantně v doktríně i judikatuře zastáván názor, že ujednání o smluvním úroku z prodlení podléhá kontrole mravnosti. Excesivní ujednání o smluvním úroku z prodlení tudíž bylo kvalifikováno jako neplatné pro rozpor s dobrými mravy. V podmínkách OZ však není zcela jasné, zda lze dosavadní závěry bez dalšího přenášet i do poměrů současné úpravy. ${ }^{1}$ Ani v odborném diskurzu přitom doposud není zastáván jednoznačný názor na to,

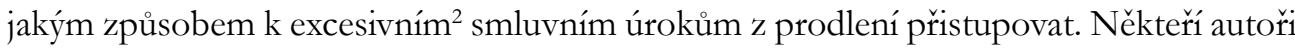
se domnívají, že by se pro řešení excesivního smluvního úroku mělo aplikovat tzv. obecné moderační pravidlo v \577 OZ. ${ }^{3}$ Jiní setrvávají na „tradičním“ závěru, že smluvní úrok z prodlení i v poměrech nové právní úpravy bude nadále podléhat toliko kontrole mravnosti. ${ }^{4}$ Ojediněle se přitom objevuje i názor, že by bylo teoreticky možné na smluvní úrok z prodlení analogicky aplikovat moderační pravidlo u smluvní pokuty zakotvené $\mathrm{v} \int 2051 \mathrm{OZ} .^{5}$

1 K této problematice (s výjimkou dále citovaného rozhodnutí Nejvyššího soudu) prozatím absentuje i relevantní judikatura.

2 Zde i dále v textu je slova „excesivni““ užito výhradně ve smyslu př́lišné intenzity smluveného úroku z prodlení. Na př́pady excesivně nízkých úroků se uplatní \1972 OZ a řešení tohoto („opačného“) typu excesů tak nečiní výkladové potíže. Tímto slovem se přitom záměrně vyhýbám i pojmu „nepřiměřeného“ úroku z prodlení, který by mohl bez dalšího indikovat, že u úroku z prodlení se shodně jako u smluvní pokuty podle \2051 OZ zkoumá kritérium nepřiměřenosti.

3 Srov. např. ONDREJOVÁ, Dana. Prưvodce uzavíráním smluv. 3. vyd. Praha: Wolters Kluwer, 2020, s. 336-338. ISBN 978-80-7598-806-5; Nebo též ŠAMAJ, Marek. Úrok z prodlení a smluvní pokuta. Pravniprostor.cz [online]. 7. 10. 2015 [cit. 3. 3. 2019]. Dostupné z: https://www.pravniprostor.cz/clanky/ rekodifikace/urok-z-prodleni-a-smluvni-pokuta

4 Srov. např. JIRSA, Jaromír. Smluvní úroky z prodlení. Nepřiměřená výše úroků. Poctivý obchodní styk. Pravniprostor.cz [online]. 18. 2. 2014 [cit. 17. 1. 2021]. Dostupné z: https://www.pravniprostor.cz/ judikatura/obcanske-pravo/smluvni-uroky-z-prodleni-neprimerena-vyse-uroku-poctivy-obchodni-styk

Srov. též ŠAFRÁNKOVÁ, Anna. Některá úskalí právní úpravy úroků z prodlení. Bulletin-advokacie.cz [online]. 14. 8. 2018 [cit. 25. 1. 2021]. Dostupné z: http://www.bulletin-advokacie. $\mathrm{cz} /$ nektera-uskali-pravni-upravy-uroku-z-prodleni

Přiměřeně srov. též HANDLAR, Jiří. In: LAVICKÝ, Petr a kol. Občanský zákoník I. Obecná část (』 1-654). Komentár. 1. vyd. Praha: C. H. Beck, 2014, s. 2066-2068. ISBN 978-80-7400-529-9.

5 ŠILHÁN, Josef. Právni následky porušeni smlouvy v novém občanském zákoníku. 1. vyd. Praha: C. H. Beck, 2015, s. 374-375. ISBN 978-80-7400-544-2. 
Veskrze je nutné nicméně uvést, že shora prezentované názory nejsou doposud v literatuře dostatečně odůvodněny či důkladně argumentovány. ${ }^{6}$ Otázka tedy zní, jakými nástroji lze obecně excesivní smluvní úroky z prodlení podle současné právní úpravy postihovat. Cílem tohoto príspěvku je proto přispět do probíhajícího diskurzu především komplexním rozborem všech potenciálně možných př́stupư řešení excesivních smluvních úroků v poměrech $\mathrm{OZ}$, a to včetně vyhodnocení jejich vhodnosti. Článek bude prritom též reflektovat recentní judikaturu Nejvyššího soudu (dále též „NS“).

\section{Teoretická východiska jednotlivých př́stupů a dosavadní judikatura}

V teoretické rovině lze v zásadě uvažovat o třech možných př́istupech, a to i) o moderaci smluvního úroku na základě analogické aplikace \2051 OZ, ii) o moderaci smluvního úroku na základě (analogické) aplikace \577OZ, iii) o neplatnosti ujednání o smluvním úroku z prodlení pro rozpor s dobrými mravy (〔 588 OZ). Kromě toho, jedná-li se o smlouvu uzavřenou adhezním způsobem, v úvahu samozřejmě připadá i změna ujednání o smluvním úroku podle \1800 odst. 2 OZ, kde je odkazováno na obdobné použití $\int 577$ OZ, je-li doložka zvláště nevýhodná a vyžaduje-li to současně spravedlivé uspořádání práv a povinností stran. Režim adheze je ovšem určitým specifikem (odchylkou od obecné úpravy). Zvláštní režim prritom dále zpravidla nastane i ve spotřebitelských vztazích ${ }^{7}$ (srov. např. \1813 a \1815 OZ) či u nájmu bytu a domu (srov. \2239 OZ). Cílem tohoto příspěvku je však úvaha nad obecným řešením v případech běžných (nikoli specifických) podnikatelských či nepodnikatelských vztahů, proto se budu dále podrobněji zabývat toliko třemi shora uvedenými př́istupy. Řešení by totiž mělo být oběma skupinám vztahů společné a v závislosti na subjektech prŕíslušného vztahu by se mělo lišit pouze v posouzení míry (intenzity), kterou shledáme jako excesivní. ${ }^{8}$

Nejprve je však zapotřebí vyjasnit si samotnou povahu jednotlivých př́stupů. Ta se liší v závislosti na předmětu kontroly a následného zásahu. V tomto ohledu je potřeba rozlišovat, zda podléhá kontrole a následnému zásahu soudu obsah smlouvy (resp. příslušné ujednánî), anebo až vzniklý nárok (nap̌r. na smluvní pokutu či úrok z prodlení

6 Ondrejová sice argumentuje ve prospěch aplikace $\int 577 \mathrm{OZ}$ tak, že s poukazem na možnost soudu nevyužít svého moderačního práva podle \577 OZ části věty za středníkem odmítá tvrzení Melzera (vycházející z německého pojetî) o nemožnosti uplatnění redukce zachovávající platnost na př́ipady neplatnosti způsobené rozporem s dobrými mravy (k tomu viz dále v textu), avšak se blíže nezabývá tím, zda je vůbec pro možnost aplikace $\int 577$ OZ dána jeho hypotéza, případně zda je třeba aplikovat př́slušné ustanovení analogicky.

7 Přitom je třeba mít na paměti, že korektivy aplikovatelné na spotřebitelské vztahy jsou zásadně přísnější.

8 Obdobně Šilhán uvádí, že „,v obchodním styku ve vz̨tabu profesionálu jsou tendence k zásabuim do smluvni svobody spiše mírnějši, ne⿻̌lli silnéjši" (srov. ŠILHÁN, op. cit., s. 261); Srov. též závěry z rozsudku NS sp. zn. 32 Cdo 1490/2019: „Prí úvabách o tom, zda je sjednaná výse úroku z prodleni jestě souladná s dobrými mravy, lze také zoblednit skutečnost, že ve vatazich mezi podnikateli, kteř vystupuji jako profesionálové, je obecně vnimáni hranice jednání, keteré již neni zpobledu dobrých mravi akceptovatelné, odlišné od vztahü nepodnikeatelských, typickey od vztabu spotrebitelskych." 
v konkrétní výši). V prvém př́ipadě tak (nejprve) zkoumáme, zda obsah smlouvy vyhovuje požadavkům na platnost právního jednání a pakliže nevyhovuje, tak jej soud může za př́islušných podmínek napravit a svým zásahem vady právního jednání odstranit. Tím však soud změní obsah smlouvy trvale. Naproti tomu v př́padě druhém je předmětem zkoumání zásadně prriměřenost konkrétního nároku, načež soud posuzuje, v jaké (přiměřené) výši požadovaný nárok přizná (resp. jak jeho výši upravî). Do obsahu smlouvy tak soud již př́mo (trvale) nezasahuje. $\mathrm{V}$ tom lze spatřovat významnou odlišnost od kategorie směrující na obsah, u níž dochází k trvalé změně obsahu smlouvy. Jakkoli i u kategorie směřující na nárok lze konstatovat, že zásahem soudu dochází zprostředkovaně i k zásahu do obsahu smlouvy (a tedy i do autonomie vưle stran), v němž má posuzovaný nárok svůj původ, jde o zásah z hlediska jeho účinků s výrazně redukovanou intenzitou, nežli tomu je u kategorie obsahové. Jednorázovou moderací výše nároku, kterou ad hoc $\mathrm{s}$ přihlédnutím $\mathrm{k}$ relevantním okolnostem shledá soud jako nepřměřenou, totiž bez dalšího nevylučujeme přměřenost v budoucnu vzniklých nároků na základě téhož smluvního ujednání. Obsah smlouvy se tudíž jen ad hoc zcela neprosadí (výše nároku určená na základě obsahu bude podléhat korekci). Naproti tomu zásah př́mo do obsahu smlouvy (např. změnou sazby úroků či smluvní pokuty) je v tomto ohledu mnohem invazivnější (více narušuje autonomii vůle stran), nebot’ má automaticky dopad na výši všech nároků, které z př́ílušného ujednání v budoucnu vzniknou, či dokonce i v minulosti vznikly (s ohledem na účinek takového zásahu ex tunc k okamžiku ujednánî).

Kategorizace př́stupů nabývá na významu i pokud jde o jednotlivá kritéria, která jsou předpokladem aplikace prŕslušných nástrojů. U kategorie obsahové se proto budou zásadně vyskytovat kritéria směřující na obsah, zatímco u kategorie směrující na nárok bude relevantním kritériem pro posouzení (ne)přiměřenost nároku in concreto. $\mathrm{V}$ textu proto doposud záměrně používám jen pojem „excesivní“ smluvní úrok, a nikoli nepřiměřený, či nemravný. Pokud totiž budu vycházet $z$ pojmu nepřiměřenosti ${ }^{10}$, s nímž jako s kritériem pracuje \2051 OZ, jedná se - v pojetí výše uvedeném - o nepřiměřenost konkrétního vzniklého nároku (nikoli ujednání o smluvní pokutě). Naproti tomu nemravnost je kategorií, kterou je třeba vztahovat k obsahu právního jednání, v tomto př́padě konkrétního ujednání. Stejně tomu je i u „důvodu neplatnosti v nezákonně určeném rozsahu“, jenž je vyžadován hypotézou \577 OZ.

Shora uvedené rozlišení má přitom význam především i pro určení okolností, které jsou relevantní pro posouzení. U kategorie směřující na obsah totiž nelze brát na zřetel okolnosti, které nastanou po okamžiku učinění posuzovaného jednání - ty jsou z hlediska požadavků na obsah právního jednání zásadně irelevantní a nemohou proto nabývat

9 K účinkům rozhodnutí viz dále v textu.

10 Lze tedy rozlišovat pojem nepřiměřenosti $\mathrm{v}$ užším slova smyslu (tj. ve smyslu $\int 2051 \mathrm{OZ}$ nepřiměřenost konkrétního nároku) a nepřiměřenosti v obecném (širším) slova smyslu, který se významově kryje s v textu užívaným pojmem excesivnosti. 
na významu ani pro účely následné soudní korekce (vadného) obsahu. Tento závěr plně konvenuje s dosavadním př́stupem rozhodovací praxe ${ }^{11}$ a doktríny ${ }^{12} \mathrm{k}$ posuzování okolností rozhodných pro zkoumání platnosti právního jednání. Nelze ovšem ponechat stranou, že stejným zpơsobem Nejvyšší soud přistupuje nejen k posuzování mravnosti sjednaných úroků z prodlení ${ }^{13}$, nýbrž i k moderaci smluvní pokuty ${ }^{14}$. Naproti tomu u kategorie směřující na nárok by měly být rozhodné především okolnosti nastalé k okamžiku jeho vzniku (tj. i okolnosti nastalé po uzavření smlouvy). Z povahy věci totiž nedává smysl posuzovat prriměřenost nároku jen podle okolností, které nastaly v době uzavření smlouvy (tj. dříve, než vůbec nárok vznikl), bez zohlednění relevantních okolností nastalých po uzavření smlouvy do okamžiku vzniku prríslušného nároku. ${ }^{15}$ Tím by se posouzení přiměřenosti nároku nijak nelišilo od posouzení „přriměřenosti“ ujednání, z něhož prríslušný nárok vzešel. Fixace rozhodných okolností jen na okamžik uzavření smlouvy by proto byla jen umělá a vedla by k faktické transformaci kontroly přiměřenosti nároku v kontrolu obsahovou.

Právě zmíněné závěry se bezprostředně odráží i v účincích př́slušných soudních rozhodnutí. Zatímco účinky rozhodnutí u nástrojů směřujících na nárok je zapotřebí vztahovat alespoň k okamžiku vzniku nároku (je v logickém rozporu moderovat nárok k okamžiku, který předchází jeho vzniku), tak u nástrojů směřujících na obsah se musí účinky rozhodnutí vztahovat k okamžiku učinění př́slušného ujednání (tj. zpravidla k okamžiku uzavření smlouvy).

Z výše uvedeného tedy rezultuje závěr, že lze obecně rozlišovat dva možné př́stupy řešení excesů smluvních sankcí, a to nástroje směřuící na obsah smlouvy (ujednání) na straně jedné (tj. zjednodušeně řečeno nástroje kontroly obsahu ${ }^{16}$ ) a nástroje směřující na kontrolu

11 Srov. např. rozsudek NS ze dne 6. 11. 2012, sp. zn. 21 Cdo 2558/2011, či rozsudek NS ČSR ze dne 28. 12. 1986, sp.zn. 1 Cz 34/86.

12 Srov. např. LAVICKÝ a kol., op. cit., s. 2077-2092.

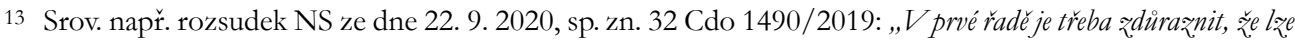
z. povahy věci, v₹̧hledem k tomu, že jde o posuzováni souladnosti či rozporu ujednánís dobrými mravy, príblédnout jen k tèm okolnostem, které existovaly v době, kedy k tomuto ujednáni došlo (tj. v době uzavréni smlouvy)."

14 Srov. např. rozsudek NS ze dne 17. 5. 2011, sp. zn. 23 Cdo 2192/2009: „Ke skutečnostem, které nastaly

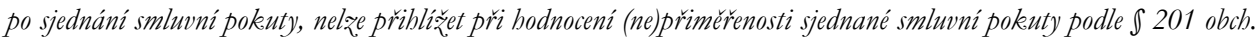
zák." Obdobně rozsudek NS ze dne 21. 6. 2011, sp. zn. 32 Cdo 944/2010: „Priměrenost smluvni pokuty lze bodnotit pouze ve və̌tahu k podminkám, jež tu byly v dobé jejího sjednání."

15 Či prípadně do jiného pozdèjšího okamžiku.

16 Pozn. Ustanovení $\ 577$ OZ není „obsahovou kontrolou“v obecném slova smyslu, tj. nezkoumá se jeho prostřednictvím př́mo to, zda př́slušné ujednání $\mathrm{z}$ hlediska svého obsahu dostojí zákonným požadavkưm (resp. nepřekračuje jeho limity). Př́slušné ustanovení především slouží k nápravě (obsahu) právních jednání, která již zákonným požadavkům nevyhovují a (nebýt \577 OZ) byla by jinak stižena neplatností. Z hlediska přezkumu (excesivních) smluvních sankcí je však klíčové, zda je předmětem přezkumu (kontroly) a následné nápravy obsah ujednání, či konkrétní nárok. V tomto ohledu $\int 577$ OZ nepochybně patř́ do kategorie směřující na obsah ujednání, nikoli na konkrétně vzniklý nárok. 
přiměřenosti ${ }^{17}$ výše konkrétního nároku na straně druhé. ${ }^{18} \mathrm{Nad}$ rámec shora řečeného lze ve stručnosti shrnout, že oba př́stupy se odlišují př́edevším v tom, co je předmětem přezkumu a současně vioči čemu konkrétně směřuje zásah soudu (ujednání x nárok). ${ }^{19}$ Právě řečené je prítom klíčové pro posouzení, jak přsstupovat k řešení excesivního smluvního úroku. Po aplikaci shora popsaných teoretických východisek na jednotlivé přístupy proto dále vycházím z předpokladu (dosavadní obchodněprávní judikaturou ${ }^{20}$ prozatím neaprobovaného), že moderace smluvní pokuty v režimu \2051 OZ stojí na předpokladu nepřiměřené smluvní pokuty, tj. konkrétně vzniklého nároku, který by měl posléze být soudem moderován. Ustanovení \2051 OZ tudíž nedává soudu pravomoc měnit obsah smlouvy (i pro futuro), nýbrž pouze odstranit nepřiměřenost v závazkovém vztahu založenou vzniklým (a věřitelem uplatňovaným) nárokem na smluvní pokutu. ${ }^{21}$ Důsledky tohoto prŕstupu by se přitom nepochybně měly projevit i v relevantních okolnostech pro posouzení neprriměřenosti (tj. rozhodné by měly být okolnosti nastalé $\mathrm{k}$ okamžiku porušenî), jakož i v účincích rozhodnutí (ex tunc k okamžiku vzniku nároku). ${ }^{22}$ Naproti

17 Ve smyslu obdobném jako v $\ 2051 \mathrm{OZ}$, a to se všemi důsledky s tím spojenými (tj. při posouzení takového kritéria je zapotřebí pruihližet ke shodným či obdobným okolnostem).

18 Jedná se pouze o zjednodušené vymezení pro účely tohoto článku. Mezi nástroje obsahové kontroly lze zařadit např́klad test platnosti (mravnosti), dále též redukci podle $\ 577 \mathrm{OZ}$, modifikaci nepřiměřeně nízkého úroku z prodlení $\ 1972$ odst. 1 OZ či kontrolu u adhezních smluv podle $₫ 1800$ odst. 2 OZ. Naproti tomu mezi nástroje „typicky nárokové“ lze zařadit moderaci smluvní pokuty podle $\$ 2051$ OZ či moderaci výše náhrady škody podle $\$ 2953$ OZ. Nejedná se však v žádném prípadě o vyčerpávající výčet v právní úpravě je korektivů nepochybně více a nelze ani vyloučit, že v závislosti na konkrétní situaci dojde k prolínání jednotlivých kategorií.

19 Není přitom rozhodné, $v$ jaké formě soud zásah do nároku učiní. Fakticky tak může učinit i prostřednictvím ad hoc změny sazby př́slušné sankce za určité období. Úvahy o př́měřenosti se ovšem $\mathrm{v}$ takovém př́padě nesměji odvijet od sazby jako takové, nýbrž od výše konkrétního nároku. Ad hoc nahrazení jinak sjednané sazby tedy může v tomto prípadě sloužit jako nástroj $\mathrm{k}$ dosažení kýženého výsledku (resp. jako nástroj pro výpočet přiměřené částky) a nesmí představovat trvalý zásah do obsahu smlouvy.

20 Tj. rozhodovací praxí préed účinností OZ, nebot' v poměrech současné úpravy Nejvyšší soud prozatím uvedené otázky věcně neposuzoval. Výjimku představuje usnesení NS ze dne 24. 9. 2020, sp. zn. 23 Cdo 2578/2019, v němž NS odmítl podané dovolání pro nepř́ípustnost (tedy neposuzoval otázky moderace věcně), avšak s poukazem na možnost uplatnění dosavadní obchodněprávní judikatury i na vztahy podléhající OZ.

21 Shodně $\mathrm{k}$ tomu Šilhán uvádí, že $\ 2051$ OZ dává soudu právo moderovat nepřmiměreně vysokou smluvnî pokutu, nikoli nepřiměřeně vysoko sjednanou (srov. ŠILHÁN, op. cit., s. 266).

Obdobný názor zastává též např. Kolmačka. Srov. KOLMAČKA, Viktor. O moderaci započtené smluvní pokuty jako protipohledávky. Obchodněprávní revue, C. H. Beck, 2019, roč. 11, č. 3. ISSN 1803-6554. Dostupné z: https://www.beck-online.cz/bo/chapterview-document.seam?documentId=nrptembrhfpw64s7gnpxgxzvg4 \& groupIndex $=0 \&$ rowIndex $=0$ [cit. 29. 3. 2019].

22 Shodně též Kolmačka uvádí, že stejný prŕstup $\mathrm{k}$ moderaci smluvní pokuty byl při obdobné právní úpravě dovozen i v Německu a Rakousku. Odkazuje přitom na zcela výstižné závěry Walchnera, že „kontrola smluvni pokuty se vatabuje na konkrétní př́pad vžšlébo nároku smluvni pokuty, nikoliv na ujednání

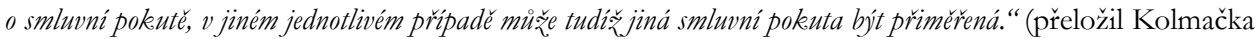
z WALCHNER, Wolfgang. In: DAUNER-LIEB, Barbara, Werner LANGEN a kol. BGB: Schuldrecht. Band 2/1. \242-610. 2. vyd. Baden-Baden: Nomos, 2012, s. 1240, § 343 marg. č. 6). Viz KOLMAČKA, op. cit. 
tomu uvažovaná \577 a \588 OZ patří nepochybně do kategorie nástrojů obsahových, nebot' jejich aplikací dochází k trvalému zásahu do obsahu smlouvy (ujednánî). ${ }^{23}$

Je ovšem na tomto místě korektní zdůraznit, že dosavadní rozhodovací praxe bohužel prozatím toto pojetí moderace smluvní pokuty nezastává, a to i přesto, že se Nejvyššímu soudu ani v nejnovějších rozhodnutích nepodařilo rozptýlit pochybnosti a logické rozpory s tímto pojetím spojené. ${ }^{24}$ Že v rozhodovací praxi Nejvyššího soudu dochází k nekonzistentnímu směšování obou prístupů s preferencí přístupu obsahového, je nepochybné. $\mathrm{V}$ tomto směru lze z četné rozhodovací praxe odkázat například na odůvodnění rozsudku NS ze dne 30. 5. 2007, sp. zn. 33 Odo 438/2005, z něhož je jasně patrný př́klon Nejvyššího soudu k posuzování „,prriměřenosti“ obsahu ujednání - sjednané sazby. ${ }^{25}$ Stejně tak v recentním rozsudku ze dne 11. 4. 2018, sp. zn. 31 Cdo 927/2016, Nejvyšší soud hovoří o „nepřiměřenosti sjednané smluvní pokuty“ a posouzení otázky, zda byla smluvní pokuta „sjednána v nepřiměřené výši“. Naproti tomu ale Nejvyšší soud explicitně převzal (správné) závěry z rozsudku Krajského soudu v Ostravě ze dne 3. 2. 1994, sp. zn. 15 Co 481/93 (publikovaného ve sbírce), podle kterého „moderovat ve smyslu \301 obch. zák. lze pouze výslednou částku smluvnípokuty, nikoli vlastni zpiosob jejího určeni (procentuální saz̧bu určujici smluvni pokutu ze stanovené částky za každý den prodleni) “. ${ }^{26} \mathrm{Z}$ převažující judikatury je nicméně patrné, že se Nejvyšší soud posledně zmíněného názoru důsledně nedrží (pokud by tak činil, musel by postupovat se všemi důsledky z tohoto př́istupu plynoucími, tak jak je popsáno shora), naopak do svého pojetí moderace smluvní pokuty vnáší řadu nekompatibilních prvků, typických především pro nástroje kontrolující a napravující obsah ujednání. ${ }^{27}$

Neudržitelnost stávajícího pojetí moderace se projevuje i v dalších rozhodnutích Nejvyššího soudu, ale i Ústavního soudu. V nálezu ze dne 1. 4. 2019, sp. zn. II. ÚS 3194/18, Ústavní soud uvedl, že „zásadni vadou exekučního titulu je také priznání úrokì z prodleni ve zcela nepriměrené výsí, která jižz neni v souladu s ústavním porádkem", přičemž úroky z prodlení ve výši $0,5 \%$ denně (182,5\% ročně) a vyšší považoval za již

$23 \mathrm{~V}$ podrobnostech viz SKOČOVSKÝ, Dominik. Soudni moderace smluvních sankí. Diplomová práce. Brno: Masarykova univerzita, Právnická fakulta, 2019. Vedoucí práce Josef Šilhán. Dostupné z: https://is. muni.cz/th/m3dwn/ [cit. 16.1.2021].

24 Srov. kontroverzní rozsudek NS ze dne 11. 4. 2018, sp. zn. 31 Cdo 927/2016. K vytýkaným problémům v podrobnostech srov. KOLMAČKA, op. cit. a SKOČOVSKÝ, op. cit.

25 „Rozhodovaci praxe Nejvyššího soudu Ceské republiky se v otázce úmèry této sankéni povinnosti již ustálila. Zatímco smluvni pokuta sjednaná ve výsi z̧ ladu s dobrými mravy, ujednáni o smluvni pokutě ve výsi 1 \% denné je považováno za neplatný právni úkon, který se prící dobrým mravim."

26 Srov. např. usnesení NS ze dne 26. 6. 2012, sp. zn. 29 Cdo 1734/2012, rozsudku NS sp. zn. 29 Cdo 3667/2010, ze dne 26. 9. 2012, nebo usnesení NS ze dne 27. 6. 2017, sp. zn. 33 Cdo 4985/2016, která na tyto závěry odkazují a přebírají je.

27 Srov. závěry NS ohledně účinků rozhodnutí, rozhodných okolností pro posouzení, jakož i „,sazebníkovou“ judikaturu, v níž je posuzována přiměřenost sazby, namísto konkrétní výše smluvní pokuty. 
„ústavně neakceptovatelné“ a není $\mathrm{k}$ nim třeba provádět individuální hodnocení př̀iměřenosti úroků. Dále konstatoval, že ,spravedlivé rovnováhy prítom bude dosaženo v prípadě, že véritel (oprávnèný) obdr ̌̌í priměrenou výši úrokư zprodlení. V návaznosti na citovaný nález Ústavního soudu vydal Nejvyšší soud usnesení ze dne 1. 7. 2020, sp. zn. 20 Cdo 1655/2020, v němž fakticky aproboval možnost exekučního soudu ${ }^{28}$ moderovat sazbu úroků z prodlení v exekučním řízení. ${ }^{29}$ Důkazem směšování obou př́ístupů budiž tvrzení Nejvyššího soudu, že odvolací soud postupoval v souladu se závěry Ústavního soudu, pokud „nevycházel toliko z kapitalizované výše nároku, ale zkoumal konkrétni okolnosti vedouci ke sjednáni úroku z.prodleni a jeho výsí, divvody nesplnèni a dopady na osobu povinnébo, cili komplexni dìvody vedouci k současné výsi nároku oprávnèné, a na základè uvedeného dovodil, že úrok z.prodleni ve výsis $1 \%$ denně z částkey 204000 Kč od 15. 4. 1994 do zaplaceni prédstavuje nárok. prícicí se zásadám právního státu“. Jinými slovy, skutečnost, zda se sjednaná sazba (tj. obsah smlouvy) př́ićí zásadám právního státu, je dovozována mimo jiné z přiměřenosti kapitalizované výše nároku, jakož i z dalších okolností nastalých po okamžiku sjednání príslušné sazby (důvody nesplnění a dopady na osobu povinného).

Lze tedy uzavř́it, že jakkoli je rozhodovací praxe v otázkách moderace smluvní pokuty či případné moderovatelnosti smluvních úroků z prodlení ve zvolených přístupech nekonzistentní, lze ojediněle vysledovat určité tendence směřující k odstranění hodnotového rozporu (k tomu viz níže) spočívajícího v tom, že zatímco u smluvní pokuty existuje kontrola obsahu (mravnosti) ujednání i kontrola přiměřenosti vzniklého nároku, u smluvního úroku z prodlení kontrola přiměřenosti nároku absentuje. ${ }^{30} \mathrm{Je}$ tomu

28 Což je přitom také samo o sobě nekonzistentní, jestliže nalézací soud podle rozhodovací praxe moderačním oprávněním nedisponuje, zatímco exekuční soud ano. Takový přístup je navíc sporný též už jen z důvodu, že zásahy exekučního soudu do vykonatelného rozhodnutí nalézacího soudu by měly být jen výjimečné a v minimálním rozsahu.

29 Srov. odůvodnění citovaného rozhodnutí: „Dospěl-li poté odvolaci soud s obledem na povahu danébo závazku a pri

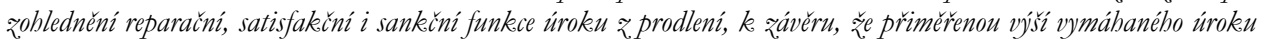
z.prodlení je v projednávané věci 0,2\% denně z dlužné částky, pričemžnárok oprávněné na úrok zprodleni ve výši 0,8\% dennè shledal protiústavním a v tomto rozsabu výkon rozhodnuti částečně zastavil, postupoval exaktněpodle výse uvedené judikatury Ústavního soudu a jeho postupu nelze nic vytknout. Dovolací soud se tak zcela príkláni k výše uvedeným závérum Ústavního soudu, že shledá-li exekučni soud po provedeni testu primérenosti neústavni (nepriměrenou) výsi

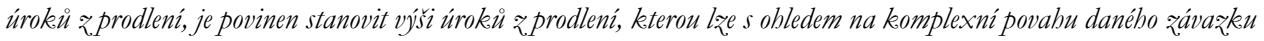
považovat za ústavní (priměrenou) a ve zbylé ćásti exekuci podle \268 odst. 1 pism. b) o. s. r. zastavit."

Pro zajímavost je vhodné uvést, že př́islušné rozhodnutí bylo navrženo k publikaci ve Sbírce soudních rozhodnutí a stanovisek s právní větou: „V rízeni o výkonu roz̧hodnuti (exekuci) lze moderovat príslušenství pobledávey roz̧hodnutím o částečném zastaveni provádèného výkonu rozhodnutí (exekuci) podle \268 odst. 1 písm. h) o. s. r., jestliže soud dospèje ke závèru, že rozhodnutim soudu v nalézacím rízeni priznané príslušenstvi pobledávky odporuje zásadám demokratického právního státu." Viz Rozhodnutí navržená k publikaci ve Sbírce soudních rozhodnutí a stanovisek (materiál pro zasedání kolegia OOK NS leden 2021). Pavel Vrcha [online]. 12. 1.2021 [cit. 16. 1. 2021]. Dostupné z: https://vrcha.webnode.cz/news/rozhodnuti-navrzena-k-publikaci-ve-sbirce-soudnich-rozhodnuti-a-stanovisek-material-pro-zasedani-kolegia-ook-ns-listopad-2016/

30 Srov. např. výše uvedené rozhodnutí sp. zn. 20 Cdo 1655/2020, kde byla mimo jiné zkoumána přiměřenost kapitalizované výše nároku na úroky z prodlení a byly vzaty v potaz i další okolnosti nastalé po okamžiku sjednání. 
tak i přesto, že judikatura si (alespoň prozatím) zřejmě př́slušného rozporu není ani vědoma, nebot' kontrolu přiměřenosti vzniklého nároku provádí u smluvních pokut sjednaných ve formě procentní sazby z určité částky denně (měsíčně/ročně) zprostředkovaně pomocí posouzení „přiměřenosti“ sjednané sazby a následné korekce požadované částky na základě moderované sazby.

\section{Nástroje směřující na obsah ujednání}

Jak již bylo výše naznačeno, problémem u smluvních úroků je onen hodnotový rozpor v komparaci se smluvní pokutou. V optice popsaných rozdílů obou kategorií přístupů je zřejmé, že nástroje směřující na obsah ujednání nemohou svými účinky zcela nahradit roli moderace nároku (resp. jeho konkrétní výše). To je dáno především tím, že u přezkumu obsahu zkrátka není zpravidla objektivně možné ani v individuálním případě stanovit jakousi paušální hranici přiměřenosti, nebot’ do závěru o přiměřenosti př́slušné smluvní sankce nutně prostupují právě i okolnosti nastalé po okamžiku sjednání (tj. v okamžiku porušenî). Závěr o nepřiměřenosti smluvní pokuty může být totiž odůvodněn mimo jiné i kupříkladu tím, že dlužník porušil smluvní pokutou utvrzenou povinnost nezaviněně $\mathrm{v}$ důsledku vyšší moci (tedy okolnosti, jež nastala po okamžiku sjednání smluvní pokuty). V důsledku trvalé změny obsahu smlouvy však nejenže není možné reflektovat veškeré skutečnosti, které by v budoucnu (po okamžiku sjednánî) mohly odůvodnit závěr o (ne)přiměřenosti smluvní pokuty, ale navíc existuje riziko nežádoucích účinků takové změny i na případy v minulosti či budoucnosti vzniklých nároků, jejichž přiměřeností se soud v konkrétním případě nezabýval (ani nemohl zabývat). Tak např́iklad z téhož ujednání o smluvní pokutě může v jednom případě vzniknout nárok, který je in concreto shledán neprriměřený, avšak posléze může vzniknout jiný nárok v téže výši a v témže smluvním vztahu, který by přitom (např. s ohledem na úmyslné porušení utvrzené povinnosti dlužníkem $\mathrm{v}$ daném případě) mohl být shledán přiměřeným. Tyto situace však př́stup směřovaný výlučně na obsah ujednání nereflektuje. Přesto však tyto nástroje mohou alespoň zčásti nedostatek právní úpravy projevující se v absenci moderace nároku na smluvní úroky z prodlení zmírňovat. Níže se proto budu zabývat též aplikovatelností jednotlivých v úvahu přicházejících nástrojů směřujících na obsah ujednání.

\subsection{Lze ujednání o smluvním úroku z prodlení moderovat podle $\mathbb{5} 57$ ?}

Hypotéza \577 OZ předpokládá důvod neplatnosti v nezákonném určení rozsahu. Jedná se tak o tzv. redukci zachovávající platnost ${ }^{31}$, tedy účelem tohoto ustanovení je zachování platnosti těch právních jednání, která by (jen a pouze) z důvodu nezákonného

$31 \mathrm{~K}$ tomu v podrobnostech srov. např. MELZER, Filip. In: MELZER, Filip a kol. Občanský zákoník:

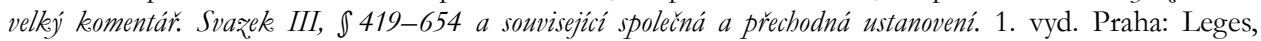
2014, s. 708-710. ISBN 978-80-7502-003-1. 
určení rozsahu jinak byla shledána neplatná. ${ }^{32}$ Existence tohoto ustanovení je projevem zásady in favorem negotii (contractus). ${ }^{33}$ Předpokladem jeho aplikace ovšem není nemravnost určení rozsahu, nýbrž jeho nezákonnost. O rozpor se zákonem se však z povahy věci nemůže jednat v situaci, kdy zákon obecně žádnou maximální možnou výši sazby úroku z prodlení (či konkrétně jeho rozsah) nestanoví. ${ }^{34}$ Je-li tak důvod neplatnosti ujednání o smluvním úroku z prodlení jen v nemravném určení výše úroku z prodlení, není hypotéza \577 OZ naplněna. Zákon přitom na různých místech rozlišuje pojem nezákonnosti a nemravnosti. Domnívám se proto, že nemravné ujednání skutečně nelze označit za „nezákonné“ ve smyslu \577 OZ. Dalším klíčovým argumentem je pak pojímání nemravnosti a následků s ní spojených. Melzer i Šilhán uvádějí, že sankce neplatnosti (pro rozpor s dobrými mravy) sleduje ochranný, sankčně-motivační a odrazující účel. Redukce zachovávající platnost by tak neměla poskytovat ochranu ujednáním, která jsou v rozporu s dobrými mravy, nebot' taková ujednání právě z těchto důvodů zákon sankcionuje absolutním zbavením jejich účinků. ${ }^{35}$

Účelem \577 OZ tak zjevně není náprava právních jednání rozporných s dobrými mravy, nýbrž zachování platnosti právních jednáních, která odporují zákonu jen z důvodu jejich nezákonného určení rozsahu. Domnívám se přitom, že účelem \577 OZ není primárně ochrana jedné ze stran smluvního vztahu (jako tomu je typicky u \2051 OZ, jehož účelem je ochrana dlužníka), nýbrž ochrana platnosti smlouvy jako takové. V konečném důsledku tedy \577 OZ chrání obě strany smluvního vztahu (resp. jejich projevenou vůli). Tím ovšem není vyloučeno, že v důsledku aplikace \577 OZ dojde k faktickému zvýhodnění (či ochraně zájmů) jedné ze smluvních stran tím, že soud modifikuje rozsah tak, aby odpovídal spravedlivému uspořádání práv a povinností stran. Existence tohoto ochranného prvku však není imanentní vlastností \ 577 OZ, nýbrž je spíše důsledkem ochranného účelu neplatnosti. Lze tedy uzavřít, že \577 OZ proto více konvenuje

32 Vycházím přitom z většinově publikovaného názoru doktríny na pojetí \577 OZ, jakož i ze systematického zařazení příslušného ustanovení v občanském zákoníku, ale též i z důvodové zprávy, z níž lze na takový účel \577 OZ usuzovat. V odborném diskurzu se však objevují i jiné (podle mého vědomí doposud nepublikované) názory na pojímání \577 OZ, podle kterých je prŕíslušné ustanovení tzv. redukcí na přiměřenou míru, což má býti odůvodňováno požadavkem změny rozsahu tak, aby odpovídal „spravedlivému uspořádání práv a povinností stran“.

33 Srov. též LAVICKÝ a kol., op. cit., s. 2065-2069.

34 Výjimku představuje tzv. lex covid (srov. \ 29 zákona č. 191/2020 Sb., o některých opatřeních ke zmírnění dopadů epidemie koronaviru SARS CoV-2 na osoby účastnící se soudního řízení, poškozené, oběti trestných činů a právnické osoby a o změně insolvenčního zákona a občanského soudního řádu). Výše (či sazba) úroků z prodlení může být limitována sektorovými regulacemi (srov. např. \} 1 2 2 \text { odst. } 1 písm. b) zákona č. 257/2016 Sb., o spotřebitelském úvěru).

35 ŠILHÁN, op. cit., s. 411.

MELZER. In: MELZER a kol., 2014, op. cit., s. 709-710.

K obdobným závěrům dospívá též Kotásek (viz KOTÁSEK, Josef. Doplñující výklad smlouvy. 1., elektronické vyd. Brno: Masarykova univerzita, Právnická fakulta, 2018, s. 86-87. ISBN 978-80-210-9148-1. Dostupné z: https://science.law.muni.cz/knihy/monografie/Kotasek_doplnujici_vyklad.pdf). 
povaha tzv. doplňujícího výkladu smlouvy ${ }^{36}$ nežli nástroje směřujícího na ochranu dlužníka stíhaného excesivně přísnou smluvní povinností.

Opačně od shora uvedených závěrů dovozuje Ondrejová aplikovatelnost $\int 577$ OZ i na nemravné ujednání o úrocích z prodlení s tím, že soud může v konkrétním př́padě moderace nevyužít, a to na základě uvážení, zda by strana k právnímu jednání vůbec přistoupila, rozpoznala-li by neplatnost včas. ${ }^{37}$ Komentářová literatura ovšem vykládá toto kritérium tak, že podle něj má být „zvažováno, zda by strana k právnímu jednání pristoupila, pokud by z něj byla zavázána v pozmènèném rozsabu, tedy v rozsabu, který nově stanovi soud svým roz̧hodnutim “" ${ }^{38}$ Jakkoli formulace věty za středníkem v \577 OZ není jednoznačná, přikláním se spíše k posledně zmíněnému názoru, tedy že príslušná část \577 OZ směřuje na rozsah změny provedené soudem, nikoli na to, zda lze ke změně rozsahu podle $\int 577$ OZ vůbec přistoupit. Usuzuji totiž, že prvně jmenovaný výklad může být pro praxi jen stěží uchopitelný. Jakým způsobem by měl soud zjišt'ovat hypotetickou vưli strany ohledně toho, zda by přistoupila k právnímu jednání vědoma si jeho neplatnosti? Výchozí úvahou by přeci měla být skutečnost, že žádná rozumně vystupující a poctivě jednající strana by k právnímu jednání s vědomím jeho neplatnosti přistupovat neměla. Pokud by tedy moderace podle $\int 577 \mathrm{OZ}$ prripadala v úvahu jen tehdy, kdyby strana prristoupila k právnímu jednání i s vědomím jeho neplatnosti, pak by se jeho aplikace na takové př́ípady minula účelem. Moderace podle $\int 577$ OZ by tak fakticky chránila kontrahenty, kteří by k právnímu jednání prristoupili, byt' by si byli vědomi jeho neplatnosti. Z čeho je dovozována legitimita takového ochranného účelu \577 OZ mi však není známo, a proto vycházím z toho, že takový účel zkrátka \577 OZ nemá. Domnívám se nadto, že posouzení, zda se určité právní jednání příčí dobrým mravům, nemůže být vázáno na vědomost krácené strany o neplatnosti takového právního jednání a její hypotetické rozhodnutí, zda by k takovému jednání s touto vědomostí přistoupila.

Shora uvedené pojetí možnosti aplikace \577 OZ i na prrípady nemravných ujednání o úrocích z prodlení nesdílím ale též proto, že se ráádně nevypořádává s tím, zda nemravná ujednání o úrocích z prodlení lze vưbec subsumovat pod hypotézu př́ílušného ustanovení, či zda je aplikovatelnost uvedeného ustanovení dovozována na základě analogie. Stejně tak není uspokojivě vyvrácena ani argumentace Melzera a Šilhána stran ochranného, sankčně-motivačního a odrazujícího účelu neplatnosti (pro rozpor s dobrými mravy).

Lze konečně též poznamenat, že za důvod neplatnosti ujednání o smluvním úroku z prodlení je judikaturou ${ }^{39}$ tradičně uváděn rozpor jeho sazby s dobrými mravy. V tomto

36 Kotásek k doplňujícímu výkladu smlouvy uvádí, že jím soud za strany utváří specifickou „náhradní výplň“, kterou zaplňují existující mezeru ve smlouvě. Mezera prritom může být také důsledkem neplatnosti právního jednání (viz KOTÁSEK, op. cit., s. 12-13). V podrobnostech k doplňujícímu výkladu srov. KOTÁSEK, op. cit., s. 7-99.

37 ONDREJOVÁ, op. cit., s. 337-338.

38 Srov. LAVICKÝ a kol., op. cit., s. 2065-2069.

39 Přičemž ani dosavadní doktrína proti tomuto přístupu neprojevila výhrady. 
směru je potřeba si klást otázku, zda je účelem zákona poskytovat ochranu právním jednáním (byt' jen částečnou), která na počátku byla nemravná (a tudíž neplatná). Jak je popsáno shora, redukce zachovávající platnost takovému účelu zjevně sloužit nemá (tj. nemá sloužit jako nástroj k dosažení souladu s dobrými mravy). To by totiž mohlo v praxi účastníky smluvních vztahů (zejména věřitele) vybízet k tomu, aby „zkoušeli průchodnost“" nemravných sazeb úroků z prodlení v přesvědčení, že jim soud vždy přizná alespoň tak vysokou sazbu, kterou bude považovat za mravnou. ${ }^{40}$ Takové „arbitrární testování“ hranic práva je nepochybně jevem nežádoucím, který stojí ve zjevné kontrapozici s ochranným, sankčně-motivačním a odrazujícím účelem neplatnosti (pro rozpor s dobrými mravy). Počáteční nemravnost právního jednání přeci nelze zhojit jen tak, že soud toliko redukuje intenzitu takového jednání.

Aplikovatelnost $\int 577$ OZ na nemravné ujednání o úroku z prodlení se proto z popsaných důvodů nejeví jako vhodná. Nepovažuji za vhodnou ani analogickou aplikaci tohoto ustanovení, nebot' zde podle mého názoru neexistuje mezera v zákoně. Ochranu, byt' se může mnohdy jevit jako př́lišná, zde totiž již zajišt'uje sama neplatnost. O hodnotovém rozporu v komparaci s úpravou moderace smluvní pokuty zde hovořit taktéž nelze, nebot' moderace smluvní pokuty - jak bylo popsáno shora - se netýká nemravného ujednání, nýbrž pouze nepřiměřeného konkrétně vzniklého nároku na smluvní pokutu. Proto usuzuji, že pro analogickou aplikaci \577 OZ nejsou splněny podmínky.

Odlišná situace by mohla nastat toliko $\mathrm{v}$ prrípadě, že bychom excesivní sazbu úroků z prodlení nepovažovali za nemravnou. Pak by teoreticky analogická aplikace \ 577 OZ v úvahu připadat mohla a zhojení obsahu právního jednání souladného s dobrými mravy by s účelem $\int 577$ OZ nekolidovalo. Žádnou takovou kategorii nevýhodných sazeb úroků ovšem zákon nezná. ${ }^{41}$

\subsection{K neplatnosti ujednání o smluvním úroku}

Z možných „obsahových“ variant řešení excesivních smluvních úroků z prodlení tak zůstává pouze možnost konstatování neplatnosti ujednání pro rozpor s dobrými mravy. Zde se ještě potenciálně nabízí možnost konstatování částečné neplatnosti ujednání podle $\int 576 \mathrm{OZ}$. Tento způsob řešení by mohl na první pohled působit elegantně. Pokud by nebylo ujednání zneplatněno jako celek, ale jen v „nevyhovující “ části, nejvyšší možnou měrou by takové řešení respektovalo původní vůli stran, která přeci směřovala ke sjednání vyšší nežli zákonné výše úroku z prodlení. Proti částečné neplatnosti

40 Přitom je třeba mít na paměti, že „mravná“ sazba ještě nutně nemusí představovat sazbu „zákonnou“. Navíc, jak bylo uvedeno shora, zákon zásadně nestanoví maximální možnou výši úroku z prodlení či jeho sazby (výjimku představuje jen výše zmíněný lex covid). Pouze podzákonný předpis stanoví subsidiárně sazbu tzv. zákonného úroku z prodlení. V konkrétních př́ípadech ale může být za „mravnou“ sazbu považována i sazba výrazně převyšující sazbu zákonnou.

41 Přiměřeně srov. úpravu v \1800 odst. 2 OZ, kde zákon upravuje „,zvláště nevýhodné doložky“. Naproti tomu ve vztahu k úrokům v obecné úpravě obdobný korektiv absentuje. 
podle \576 OZ ale hovoř́ stejné argumenty jako proti aplikaci \577 OZ. V situaci, kdy je ujednání posouzeno jako nemravné, musí s ním být takto zacházeno v jeho celku. Nelze tedy část sazby oddělit a považovat ji za mravnou, když k závěru o nemravnosti ujednání v souladu se shora řečeným nelze přistoupit toliko z posouzení její výše. Ujednání je proto nemravné (a neplatné) jako celek a v takovém př́padě mu nelze ani zčásti poskytovat právní ochranu. Domnívám se, že zde krom shora řečeného není ani splněna hypotéza př́slušného ustanovení (tj. nejedná se o část právního jednání, kterou by bylo možné od ostatního obsahu oddělit) a tudíž je možnost jeho aplikace i z tohoto důvodu vyloučena. ${ }^{42}$ Pouze pro úplnost je třeba též poznamenat, že na tomto závěru ničeho nemůže změnit ani preference platnosti právního jednání zakotvená v $\int 574$ OZ. Uvedené pravidlo má totiž interpretační povahu a jeho primární funkce tkví především u výkladu obsahu právních jednání. ${ }^{43}$

Lze tedy uzavřít, že pokud soud shledá ujednání o smluvním úroku z prodlení rozporným s dobrými mravy, může jej patrně v takové situaci jen prohlásit za neplatné jako celek. Důsledkem toho by měla logicky být skutečnost, že v př́padě neplatnosti takového ujednání automaticky nastoupí namísto neplatně smluvené výše úroku sazba stanovená nař́zením vlády.

\section{Nástroje směřující na kontrolu přiměřenosti výše nároku - lze moderovat analogicky podle $\mathbb{2 0 5 1} \mathrm{OZ}$ ?}

Třebaže ujednání o smluvní pokutě nepochybně podléhá kontrole mravnosti, moderace smluvní pokuty v režimu \2051 OZ však již v duchu shora prezentovaného názoru obsahovou kontrolou ujednání není. Naopak \ 2051 OZ (shodně jako v zahraničních právních řádech, které koncipují moderační právo soudu u smluvní pokuty obdobným způsobem ${ }^{44}$ ) postihuje až konkrétně vzniklý (nepřiměřeně vysoký) nárok na smluvní pokutu. Podle účinné právní úpravy tak u institutu smluvní pokuty podléhá kontrole jak samotné ujednání, tak i z něj konkrétně vzniklý nárok. ${ }^{45}$

42 Lze přiměřeně odkázat i na závěry z usnesení NS, sp. zn. 33 Cdo 4322/2007, které (byt' byly učiněny v poměrech dosavadní úpravy) mohou být kompatibilní i se současnou právní úpravu: „Oddělitelnost části právního úkonu od ostatního jebo obsabu je treba vždy dovodit výkladem zpovaby právního úkonu anebo z jeho obsahu anebo zokolností, za nichž ke nèmu došlo. Neoddèlitelnost je tak třeba chápat ve smyslu obsahovém nikoliv reálné neoddèlitelnosti; podle zásady favor negotii je pak treba dávat prednost prìstupu, který jinak zachovává ostatni cásti smlouvy. Prípadná neurčitost dobody obledné úplaty za poskytnutou pịjčku nemǐze zpuisobit neplatnost (celébo) právního úkonu. Neurčitost ujednáni oblednè smluvených úroku mưře být dìvodem neplatnosti jen té cásti právního úkonu, která se smluvených úrokì týká, a nikoli neplatnosti právního úkonu v celém rozsahu."

43 K tomu srov. např. LAVICKÝ a kol., op. cit., s. 2055-2059.

44 Podrobně to shrnuje ve svém článku Kolmačka, který poukazuje na německou, rakouskou a švýcarskou doktrínu (při obdobné právní úpravě) - KOLMAČKA, op. cit.

$45 \mathrm{~K}$ tomu v podrobnostech srov. SKOČOVSKÝ, op. cit. 
Naproti tomu úprava smluvního úroku z prodlení nic takového nezná. Kontrola mravnosti ujednání (jak ostatně naznačuje i aktuální rozhodovací praxe) patrně nedozná změn a bude zachována i v poměrech OZ. Není důvod, proč by tomu tak nemělo být. Absentuje však právní instrument, který by chránil dlužníka před (již vzniklým) nepřiměřeně vysokým úrokem z prodlení, zatímco u smluvní pokuty, tedy institutu svým účelem a funkcemi velmi podobným, tuto ochranu zákon dlužníkovi poskytuje prostřednictvím ऽ $2051 \mathrm{OZ}$.

Dosavadní rozhodovací praxe nepřiměřenost smluvního úroku z prodlení nikdy nezkoumala. S ohledem na zvolenou koncepci přezkumu excesů pro to přirozeně ani nebyl důvod. Jakékoli úvahy o „neprriměřenosti“ úrokư ${ }^{46}$ proto doposud nalézají svého odrazu pouze $\mathrm{v}$ kontrole mravnosti prríslušného ujednání. V kontextu soudem moderovatelné smluvní pokuty pak ale prezentované nazírání na excesivní úroky z prodlení působí poněkud nekonzistentně (jak bude dále v textu vysvětleno).

Vyvstává proto otázka, zda je soud oprávněn smluvní úrok z prodlení (či ujednání o něm) nějakým způsobem modifikovat (tj. nikoli jen v celém rozsahu „zneplatnit“ pro rozpor s dobrými mravy), a to bud' prostřednictvím zásahu do obsahu ujednání, anebo prostřednictvím zásahu až do v konkrétním prrípadě vzniklé výše úroku z prodlení (t). obdobně jako u smluvní pokuty upravit až výši dlužníkova dluhu, který již v důsledku prodlení vznikl; nikoli sazbu obsaženou v ujednánî).

V tomto směru se nabízí úvaha, že zákonodárce ustanovením \1972 OZ prezentuje svoji vưli postihovat jen ujednání zakládající nepřiměřeně nízké úroky z prodlení, a tudíž neprriměřeně vysoké úroky z prodlení zvláště postihovat nezamýšlel (s výjimkou obecného přezkumu mravnosti ujednánî). S takovým závěrem se však nelze bez dalšího spokojit (a to už jen z toho důvodu, že \ 1972 OZ byl do zákona včleněn v důsledku požadavků tzv. směrnice proti opožděným platbám ${ }^{47}$ a nelze $z$ toho tak bez dalšího dovozovat vưli zákonodárce, že excesivně vysoké úroky kontrole nepodléhajî).

Uvažujme totiž dva modelové př́ípady. Oba se budou svojí povahou zcela shodovat, jedinou odlišností bude pouze stranami zvolený institut postihující prodlení dlužníka, který má však v obou př́padech plnit téže funkce. V jednom případě si ale strany za tímto účelem sjednají smluvní pokutu ve výši určité procentní sazby denně, zatímco v druhém případě si sjednají smluvní úrok z prodlení v téže výši procentní sazby denně. V obou př́ipadech vzniknou v důsledku prodlení dlužníka nároky na smluvní pokutu, resp. smluvní úrok, které budou podle kritérií pro posuzování nepřiměřenosti smluvní pokuty nepřiměřené. Pokud bychom se striktně drželi zákonné úpravy, tak zatímco nárok na smluvní

46 Rozhodovací praxe se doposud zabývá pouze přiměřeností sjednané sazby (tj. obsahu).

47 Srov. čl. 7 směrnice Evropského parlamentu a Rady 2011/7/EU ze dne 16. 2. 2011, o postupu proti opožděným platbám v obchodních transakcích, jejímž cílem je „boj proti opoždèným platbám v obchodnich transakcich s cílem zajistit rádné fungováni vnitřního trhu, a tím podporit konkurenceschopnost podnikü, a zejména malých a strednich podniku." 
pokutu lze (v př́padě jeho nepřiměřenosti) podle \2051 OZ moderovat, u úroku z prodlení tuto možnost nemáme (nebot's neprriměřeným úrokem z prodlení zákon obecně žádné explicitní důsledky nespojuje). Je tento př́stup ale správný?

Abychom uvedenou otázku mohli zodpovědět, je potřeba se nejprve zabývat komparací obou zkoumaných institutů. Jaké znaky mají společné, jaké naopak rozdílné. Je přitom nutné určit, které z těchto znaků jsou z hlediska „moderovatelnosti“ těchto institutů vưbec relevantní. Nikoli každá odlišnost totiž musí nutně odůvodňovat závěr o tom, že smluvní pokutu je legitimní moderovat, zatímco u úroku z prodlení této ochrany dlužník nepožívá. Klíčová bude nepochybně komparace obou institutů z hlediska jejich (zamýšlených) funkcí či účelu. Domnívám se totiž, že na nepřiměřenost nároku na smluvní pokutu lze usuzovat právě z toho, že takový nárok již výrazně přesahuje hranici, v níž je ještě způsobilý plnit zamýšlené funkce či účel (tj. v tom rozsahu, v němž smluvní pokuta již objektivně neplní svoje zamýšlené funkce či účel a stává se pouhou bezúčelnou sankcí, je již nepřiměřená). Moderace je nástrojem, který tyto, byt' smluvně sjednané, ale objektivně s přihlédnutím ke všem okolnostem nelegitimní, následky porušení smlouvy v tomto rozsahu zbavuje účinků a chrání tak dlužnou stranu.

\subsection{Komparace obou institutů v historickém kontextu}

Pro lepší názornost v článku řešených problémů je vhodné zabývat se tím, jak byly oba instituty $\mathrm{v}$ našem právním řádu chápány historicky. Řádná komparace obou institutů ve všech níže uvedených dobách by nepochybně vydala na rozsáhlou monografii. Tento článek si ovšem neklade za cíl takto podrobnou a komplexní komparaci provádět. Cílem této části prŕíspěvku je však nabýt jistého „předporozuměni““ řešených problémů a určitým způsobem tak dokreslit původ jejich vzniku, který je podle mého názoru z historického vývoje nepochybně patrný.

Předně je vhodné uvést, že úrok z prodlení a smluvní pokuta mají historicky svưj společný původ v náhradě škody. ${ }^{48}$ Již obecný zákoník občanský (dále jen „OZO“) rozlišoval mezi smluvní (tehdy konvencionální či konvenční) pokutou a úroky z prodlení. Systematicky byly $\mathrm{v}$ předpise oba instituty řazeny u náhrady škody (druhý díl, hlava třicátá, o právu na náhradu škody a zadostiučiněnî). Ustanovení \1333 OZO stanovilo, že „škoda, kterou zpuisobil dlužnik svému vériteli prodlením splacením dlužnéjistiny, nahrazuje se

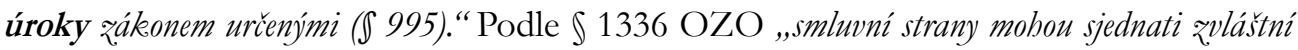
úmluvu, že má býti místo újmy, která se má nahraditi, qapravena určitá peněžitá nebo jiná cástka

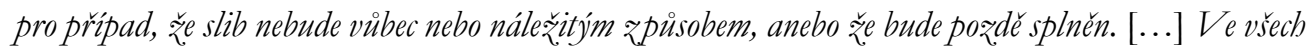

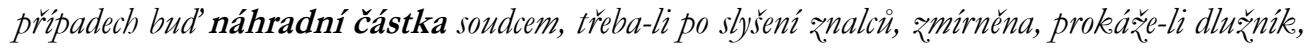
že jest př́ilišná."V obou př́padech je tak patrná výrazná vazba na náhradu škodu. Lze proto nepochybně usuzovat, že primárním účelem úroků z prodlení i smluvní pokuty

48 Srov. např. PATĚK, Daniel. Smluvni pokuta v obchodnich vqtazích. 1. vyd. Praha: C. H. Beck, 2006, s. 63. ISBN 80-7179-538-0. 
byla historicky formou náhrady škody (v paušalizované podobě). Kovařík v této souvislosti uvádí, že smluvní pokuta a úroky z prodlení jsou potom ,jen dvěma blízkými vétvemi tébož stromu, to je nábrady škody"49

V odborném diskurzu k $\int 1333$ OZO bylo sporu, zda s ohledem na dikci tohoto ustanovení se hradí úroky z prodlení tehdy, když škoda věřiteli vưbec nevznikne (resp. zda věřitel musí existenci škody, která má být nahrazena úroky, prokazovat). V komentáři k př́islušnému ustanovení Kubeš poukázal na jeho doslovné znění, které spíše nasvědčuje názoru, že existence škody je nutná. Naproti tomu však odkázal na odlišná pojetí tehdejší právní vědy, když kupříkladu Randa zastával názor, že věřitel má na zákonné úroky z prodlení nárok bez ohledu na to, zda nějakou škodu utrpěl. ${ }^{50}$ Sedláček k $\int 1333$ OZO bez jakýchkoliv pochyb uvedl, že zákonné úroky z prodlení je třeba platit i bez ohledu na to, zda věritel nějakou škodu utrpěl, či ne. ${ }^{51}$ Citovaná komentářová literatura se př́itom nevyjadřovala $\mathrm{k}$ tomu, zda bylo možné sjednat si (samostatně) smluvní výši úroku z prodlení. Není ale důvod se domnívat, že by tuto možnost tehdejší právní úprava smluvním stranám zapovídala. Sazba úroků z prodlení přitom navíc mohla být nepochybně fakticky ovlivněna $v$ důsledku smluvené úrokové míry (tj. smluvených „běžných“ úroků, nikoli úroků z prodlenî), když v případě prodlení dlužníka platila vždy sazba vyšší (tj. např. při sjednané úrokové míře $4 \%$ platila zákonná sazba úroku z prodlení ve výši $5 \%{ }^{52}$, avšak při sjednané úrokové míře $7 \%$ již platila tato sazba, nebot' zákonné úroky z prodlení jsou v ní již obsaženy). ${ }^{53}$ Z rozhodovací praxe lze též vysledovat, že věřitel mohl požadovat vyšší než zákonné úroky, pokud by prokázal, že mu prodlení dlužníka způsobilo větší škodu. ${ }^{54}$ Úroky přitom ani nebylo možné prùiznat do budoucna. ${ }^{55}$

Pouze pro zajímavost lze na tomto místě v rámci stručného exkurzu uvést, že pozdější občanský zákoník z roku 1950 (zákon č. 141/1950 Sb.) v S 255 explicitně stanovil

49 KOVAŘíK, Zdeněk. Smluvní pokuta. Právní roz̧bledy, 1999, roč. 7, č. 9, s. 454-466. ISSN 1210-6410.

50 KUBEŠ, Vladimír. in: ROUČEK, František, Jaromír SEDLÁČEK a kol. Komentár k československému obecnému zákoníku občanskému a občanské právo platné na Slovensku a v Podkarpatské Rusi. Díl pátý, (I 1090 až 1341). Reprint původního vydání. Praha: ASPI publishing, 2002, s. 962. ISBN 80-85963-90-6.

51 SEDLÁČEK, Jaromír. Obligačni právo. Obecné nauky o právnich jednáních obligačnich a o splnèni závazkeủ. 2. vyd. Brno: Nákladem československého akademického spolku „Právník“, 1933, s. 273. Dostupné z: https:// digi.law.muni.cz/handle/digilaw/12872

$525 \%$ byla obecná sazba, prritom však existovala i speciální ustanovení stanovující sazbu jinou.

53 SEDLÁČEK, op. cit., s. 273.

54 S poukazem na tehdejší judikaturu Kubeš (KUBEŠ. In: ROUČEK, SEDLÁČEK a kol., op. cit., s 956). Srov. též např. rozhodnutí Nejvyššího soudu ze dne 24. 3. 1928, Rv II 451/27. Převzato z VÁŽNÝ, František. Rozhodnutí nejvyššriho soudu československé republiky ve věcech občanských. Roćník desátý (od čisla 7678 do císla 8598), obsabujici roz̧hodnutí z roku 1928. Praha: Právnické vydavatelství JUDr. V. Tomsa, společnost s. r. o., 1929, č. 7916, s. 489-493. Dostupné z: https://digi.law.muni.cz/handle/digilaw/4423

55 Srov. např. právní větu z rozhodnutí Nejvyššího soudu ze dne 18. 11. 1943, R I 159/43: „Rozsudkem vyneseným o blavni pobledávce lz̧e s úcinkem právni moci roz̧odnuti jen o úrocích dospèlých do dne vydání rozsudku, nikoliv též o urocich dospivajicich po této dobè." 
možnost smluvního ujednání nižších než zákonných úroků z prodlení (a contrario lze tak usuzovat, že úroky ve vyšší než zákonné výši si strany zřejmě ujednat nemohly). ${ }^{56}$ To mohlo hrát významnou roli v opomenutí úvah o př́padné moderaci nepřiměřených úroků, nebot' s jejich nepřiměřeností se zkrátka historicky př́liš nepočítalo (a nebylo tomu tak právě ani ve zmiňovaném OZO, kde byly úroky z prodlení silně navázány na náhradu škody). Těmto úvahám nezavdal příčinu ani následný vývoj právní úpravy, nebot' výslovnou možnost sjednání smluvních úrokủ (též vyšších než zákonných) zakotvoval prakticky až zákon č. 513/1991 Sb., obchodní zákoník, jenž byl posléze zjevnou inspirací i pro úpravu v OZ.

Vrátíme-li se zpět k OZO, nelze ponechat stranou ani skutečnost, že v jeho poměrech bylo důsledně rozlišováno mezi prodlením objektivním a subjektivním. Spornou totiž byla otázka, zda může věritel požadovat i náhradu škody, která přesahuje částku úroků z prodlení. Doktrína dovozovala, že toto oprávnění věřiteli nepřísluší v prrípadech objektivního prodlení, zatímco $\mathrm{v}$ případech subjektivního prodlení může věřitel požadovat i další škodu. ${ }^{57}$ Shodný názor aprobovala i tehdejší judikatura, podle které \1333 OZO nevylučuje právo věřitele na náhradu další škody vzniklé v důsledku prodlení dlužníka. ${ }^{58}$ Úroky z prodlení představovaly tak ve své podstatě kompenzaci za to, že věřitel po dobu prodlení dlužníka nemohl nakládat s penězi, které mu dlužník neoprávněně zadržoval. Lze dokonce říci, že plnily roli jakési paušalizované ceny dlužných peněž. ${ }^{59}$

Vedle toho byl spatřován význam konvenční pokuty v motivační funkci pro dlužníka a v usnadnění postavení věritele tím, že nemusí prokazovat vznik a výši škody. ${ }^{60}$ Primární účel konvenční pokuty nebyl sankční, nýbrž kompenzační. ${ }^{61}$ Soudcovské právo zmírňovací (moderační právo soudu) pak sledovalo účel ochrany stran před neoprávněným vykořist'ováním, jakož i před neopodstatněnými výhodami jedné ze stran na úkor druhé. ${ }^{62}$ Moderační právo se uplatňovalo i v obchodních vztazích. Zajímavostí je, že důvodem pro zmírnění pokuty byla podle tehdejší judikatury i liknavost věřitele s vymáháním dluhu. Podle tehdejších závěrů Nejvyššího soudu totiž nelze od věritelovy pasivity odhlížet. Navíc taková pokuta (u níž věritel otálí s jejím vymáháním) pozbývá povahy trestu

56 Srov. \ 255 zákona č. 141/1950 Sb., občanského zákoníku.

57 KUBEŠ. In: ROUČEK, SEDLÁČEK a kol., op. cit., s. 962.

58 Srov. např. rozhodnutí Nejvyššího soudu ze dne 7.9. 1920, Rv I 323/20 (Rc 651/1920), rozhodnutí Nejvyššího soudu ze dne 3. 7. 1923, Rv I 163/23 (Rc 2805/1923) či rozhodnutí Nejvyššího soudu ze dne 7. 7. 1920, Rv. I 282/20 (Rc 576/1920).

59 Shodně ŠAFRÁNKOVÁ, op. cit.

60 KUBEŠ. In: ROUČEK, SEDLÁČEK a kol., op. cit., s. 969.

61 Např. Krčmář uvedl, že podle tehdejší právní úpravy nemá konventionální pokuta povahu trestu, poněvadž, „nevæešla-li škoda, odpadne povinnost zapraviti pokutu konventionálni“. Viz KRČMÁŘ, Jan. Právo občanské. III., Právo obligační. Praha: Nákladem Spolku československých právníků „Všehrd“, 1929, s. 92-94. Dostupné z: https://digi.law.muni.cz/handle/digilaw/15241

62 ROUČEK, SEDLÁČEK a kol., op. cit., s. 974. 
a stává se již jen odškodněním. ${ }^{63}$ Za zmínku pak stojí též skutečnost, že podle doslovného znění zákona měla býti zmírněna „náhradní částka“ (srov. \1336 OZO), nikoli př́slušné ujednání o konvencionální pokutě.

Ze shora řečeného lze tedy dovozovat, že oba instituty primárně měly plnit kompenzační funkci a zpravidla usnadňovat věřiteli cestu k vymožení škody, která mu vznikla. Sankční funkce byla u úroků z prodlení i smluvní pokuty výrazně upozaděna, a to v důsledku silné vazby obou institutů na náhradu škody. Toho si lze všimnout již z formulace obou zákonných ustanovení, kdy konvencionální pokuta měla představovat částku, která se má hradit „místo újmy, která se má nahraditi“ a u úroků je stanoveno, že se jimi nahrazuje škoda způsobená prodlením. O zvýšeném významu náhrady škody pro konvencionální pokutu však svědčí i to, že u moderačního práva soudu byly při posuzování př́lišnosti pokuty zvažovány otázky výše škody (a to jak skutečně vzniklé, tak i potencionálnî). ${ }^{64}$

\subsection{Komparace obou institutů v kontextu současného práva}

Jakkoli vazba na náhradu škody u obou institutů i dodnes přetrvává, je potřeba konstatovat, že v současnosti již není natolik silná, jako tomu bylo v dobách OZO. I současné vnímání obou institutů doznalo v průběhu času výrazných změn. Smluvní pokuta i úroky z prodlení sice stále plní i kompenzační funkci, s ohledem na dispozitivitu zákona ji však ani vůbec plnit nemusí. Přitom právě v důsledku postupného rozmělňování původně těsného sepětí obou institutů s náhradou škody nabývá na významu především funkce sankční. ${ }^{65}$

Popsaný historický vývoj právní úpravy - paralelně doprovázený postupnou korekcí doktríny i praxe - nakonec vede ke stírání rozdílů mezi oběma instituty. Šilhán v tomto ohledu uvádí, že úroky z prodlení a smluvní pokuta jsou instituty extrémně blízké, přičemž úroky z prodlení lze dokonce funkčně považovat za speciální případ smluvní pokuty. ${ }^{66}$

Ze současné právní úpravy ovšem plynou některé odlišnosti mezi oběma instituty. Ty spočívají především v povaze daného nároku (úrok z prodlení je na rozdíl od smluvní

63 Srov. rozhodnutí Nejvyššího soudu ze dne 16. 9. 1925, Rv I 1070/25 (Rc 5278/1925).

64 Srov. KUBEŠ in: ROUČEK, SEDLÁČEK, a kol., op. cit., s. 972.

65 Podle Bejčka je ,úrok zprodleni trestem za to, že si jedna strana bez svolenípartnera čerpá na jeho úkor vynucený úvěr" (srov. BEJČEK, Josef. Právní úprava a interpretační problémy smluvních pokut a úroků z prodlení. Casopis pro právní védu a praxi, Brno: Masarykova univerzita, 1995, roč. 3, č. 1, s. 41. ISSN 1805-2789. Dostupné z: https://journals.muni.cz/cpvp/article/view/9493/9031). Třebaže se jedná o závěr učiněný v poměrech obchodního zákoníku, stejné tendence přetrvávají i dodnes (a to právě i s ohledem na podobnost současné úpravy).

66 V podrobnostech srov. ŠILHÁN, op. cit., s. 349-352; či ŠILHÁN, Josef. In: HULMÁK, Milan a kol. Občanský zákoník: komentár (V), Závazkové právo: obecná část (』 1721-2054). Praha: C. H. Beck, 2014, s. 1048-1081. ISBN 978-80-7400-535-0. 
pokuty príslušenstvím hlavní pohledávky) ${ }^{67}$ a způsobu jeho vzniku (úrok z prodlení nastupuje automaticky ex lege $e^{68}$, zatímco ke smluvní pokutě je třeba zvláštního smluvního ujednánî). Další odlišnosti lze spatřovat zejména ve vztahu k náhradě škody (smluvní pokuta $v$ obecném režimu nárok na náhradu škody vylučuje, zatímco úrok z prodlení se na náhradu škody dle ust. \1971 OZ pouze započítává) a v ryze peněžitém charakteru úroku z prodlení (smluvní pokutu lze naopak sjednat i jako nepeněžitou a jejím prostřednictvím lze navíc utvrdit i nepeněžité povinnosti). ${ }^{69}$ Popsané rozdíly ovšem veskrze nedeterminují (ne)moderovatelnost toho kterého institutu.

Nelze ovšem naopak odhlédnout od skutečnosti, že z konstrukčního hlediska je (smluvni) úrok z prodlení de facto totožný se smluvní pokutou sjednanou jako opakující se (peněžité) plnění pro prípad prodlení, která je (nejen) v obchodní praxi velice běžná. Z funkčního hlediska tomu není (resp. v konkrétních případech nemusí být) jinak a shodný názor se objevuje i v komentářové literatuře. ${ }^{70}$ Přesto se judikatura již před účinností OZ ustálila ${ }^{71}$ na opačném názoru, tedy že oba instituty plní odlišnou funkci. ${ }^{72}$ Př́ikladmo lze zmínit závěry z rozsudku Nejvyššího soudu ze dne 20. 3. 2012, sp. zn. 32 Cdo 4920/2010: „I kedyžje smluvni pokuta sjednána formou odpovidajici úroku zprodlení, je stále o dva rozdílné právní instituty, lišici se nejen svým charakterem, ale též účelem a funkci (ürok z.prodleni jako príslušenstvi pobledávky je zákonným dùsledkem prodleni oproti smluvni pokutè jako zpuisobu zajištèni závazk.u)."73 Je otázkou, nakolik uvedená odlišnost souvisí s meritem věci. Skutečnost, že úrok z prodlení (a to i když je smluvním ujednáním určena jeho výše) je oproti smluvní pokutě př́íslušenstvím pohledávky, je uměle konstruována toliko zákonem ${ }^{74}$ a nikterak neodůvodňuje závěr o funkční a účelové odlišnosti obou sankcí. ${ }^{75}$ Právní konstrukce nároku není přeci determinující pro zjištění konkrétního účelu daného institutu. Účel konkrétního institutu do značné míry určují samy smluvní strany tím, jakým způsobem, za jakých okolností a s jakým záměrem daný institut použiji. ${ }^{76}$

67 Přitom tato skutečnost má vliv i na další odlišnosti v obou institutech (například promlčení).

68 Zde je však třeba rozlišovat zákonný úrok z prodlení a úrok smluvní, u něhož je stejně jako u smluvní pokuty zapotřebí zvláštního smluvního ujednání.

69 ŠILHÁN, op. cit., s. 349-351.

70 Srov. např. PETROV. In: HULMÁK a kol., op. cit., s. 358; ŠILHÁN, op. cit., s. 350.

71 Byt' se ojediněle vyskytují i rozhodnutí, která v jiných poměrech tvrdí opak.

72 ČECH, Petr. Smluvní pokuta versus úrok z prodlení. Právní rádce, 2008, roč. 2008, č. 4, s. 22 . ISSN 1210-4817.

73 Rozsudek NS ze dne 20. 3. 2012, sp. zn. 32 Cdo 4920/2010.

74 Obdobně ŠILHÁN, op. cit., s. 350.

75 Mimo to, s oběma instituty zákon na řadě místech zachází totožně. Srov. např. úpravu odstoupení od smlouvy (\} 2 0 0 5 \text { odst. } 2 \text { OZ), nebo postoupení pohledávky (\ } 1 9 3 7 \text { odst. } 2 \text { OZ). }

76 Obdobně PETROV. In: HULMÁK a kol., op. cit., s. 358. 
V prrípadě smluvních úroků z prodlení a smluvní pokuty sjednané ve formě odpovídající úroku z prodlení se přitom jedná o dvě konstrukčně identicky vystavené smluvní sankce, jejichž podstatou je postihnutí dlužníka opakující se peněžitou sankcí za jeho prodlení s peněžitým plněním. V konkrétním př́padě navíc mohou plnit zcela totožné funkce. Oba instituty mají společně kompenzační funkci, nebot' nahrazují věřiteli utrpěnou újmu (nebo její část). V tomto ohledu se úrok z prodlení od smluvní pokuty liší jen v tom, že náhradu škody v obecném režimu zcela nevylučuje, nýbrž se na ni započítává (srov. \2050 ve spojení s \1971 OZ). Společným znakem je i funkce sankčně-motivační, která se projevuje v preventivním působení na dlužníka, který je pod hrozbou sankce stimulován k řádnému a včasnému plnění. ${ }^{77} \mathrm{~S}$ kompenzační a sankční funkcí může úzce souviset též funkce satisfakční, která se projevuje v určitém zadostiučinění pro věřitele za to, že jeho smluvní partner smlouvu porušil. ${ }^{78}$ Smluvní pokuta i úrok z prodlení dále shodně mají převážně utvrzující charakter. Působí i tzv. nárokově-usnadňující funkcî ${ }^{79}$, nebot' věřiteli k uspokojení nároku pouze postačí prokázat prodlení (případně porušení jiné utvrzené smluvní povinnosti u smluvní pokuty). Věřitel proto pro uspokojení svého nároku na smluvní pokutu nebo úrok z prodlení nemusí „složitě“ prokazovat vznik a výši škody, která mu v důsledku dlužníkova porušení povinnosti vznikla. ${ }^{80}$

Z konstrukčního i funkčního hlediska lze proto dovozovat, že se jedná o instituty vykazující vysokou míru podobnosti a z hlediska soudní moderace by proto mohlo být možné na ně nahlížet totožně. Dílčí odlišnosti ${ }^{81}$, jež lze mezi nimi spatřovat, lze považovat pouze za specifika konkrétního institutu, která neodůvodňují vytváření umělé bariéry mezi oběma instituty, jíž se prozatím drží recentní judikatura. ${ }^{82}$ Neexistuje-li v tomto směru relevantní (konstrukční či funkční) odlišnost mezi oběma instituty, která by skutečně odůvodňovala $\mathrm{v}$ jednom př́ipadě využít moderační právo a v druhém nikoli, je zapotřebí nalézt důvody pro rozdílné zacházení s oběma instituty jinde. Komparace konstrukce, funkcí a účelu obou institutů nám totiž legitimitu odlišného zacházení s oběma instituty nezdůvodní. Aby však bylo možné učinit závěr o analogické aplikaci \2051 OZ, museli bychom nejprve dovodit existenci mezery v zákoně. $\mathrm{V}$ opačném případě analogie není možná. Na mezeru v zákoně přitom nelze bez dalšího usuzovat jen z toho, že u úroku z prodlení (nepřiměřeně vysokého) zákon mlčí a soudu moderační právo jako u smluvní pokuty nedává.

77 K funkcím úroků z prodlení a smluvní pokuty shodně srov. nap̌̌. ŠILHÁN, op. cit., s. 349, 391.

78 Oba instituty tak mohou představovat i jakousi satisfakci za nehmotnou (byt' i právně irelevantnî) újmu, kterou v důsledku dlužníkova porušení věritel utrpěl (mohl utrpět).

79 ŠILHÁN, op. cit., s. 350.

80 Obdobně srov. též HARRER, Friedrich a Erika M. WAGNER. In: SCHWIMANN, Michael, Georg E. KODEK a kol. ABGB: Praxiskommentar. Band 6. 4. nově přepracované vyd. Wien: LexisNexis, 2016, s. 837. ISBN 978-3-7007-5913-3.

81 Šilhán jejich výčet komplexně shrnuje ve své monografii. Srov. ŠILHÁN, op. cit., s. 351.

$82 \mathrm{~V}$ podrobnostech srov. SKOČOVSKÝ, op. cit. 
Stranou výše popsaných hmotněprávních aspektů chování obou institutů stojí však ještě rovina procesně-právní. Smluvní pokutu, byt' sjednanou ve formě odpovídající úrokům z prodlení, nelze soudním rozhodnutím prriznat do budoucna. Oproti tomu úroky z prodlení jsou považovány za tzv. opětující se dávku a lze je proto ve smyslu \ 154 odst. 2 zákona č. 99/1963 Sb., občanského soudního řádu, přiznat do budoucna. ${ }^{83} \mathrm{~K}$ takovému pojímání přistoupil ve své judikatuře Nejvyšší soud především z důvodu, že smluvní pokuta není příslušenstvím pohledávky (ani opětujícím se plněním), nýbrž samostatným nárokem, který v prrípadě smluvní pokuty sjednané ve formě odpovídající úrokům z prodlení vzniká vždy každým dnem prodlení (oproti tomu povinnost dlužníka zaplatit úroky z prodlení vzniká jednorázově v den prodlenî), a tudíž se takto vznikající jednotlivé nároky na smluvní pokuty na rozdíl od jednotného nároku na zaplacení úroku z prodlení nepromlčují jako jeden celek (přesněji řečeno se nepromlčují s přihlédnutím ke dni, kdy se dlužník dostal do prodlení, nýbrž vždy ke dni, kdy každý jednotlivý nárok v důsledku trvajícího prodlení vznikal). ${ }^{84}$

Je přesto otázkou, zda shora popsaný rozdíl v procesním uplatňování nároků ze smluvní pokuty a úroků z prodlení je z hlediska (ne)moderovatelnosti smluvních úroků z prodlení vůbec podstatný. Nedomnívám se, že by judikaturou zaužívaný model představoval (nepřekonatelnou či neměnitelnou) překážku pro moderaci úroků, ani že by snad mohl sloužit jako obhajitelný argument pro zdůvodnění odlišného zacházení s oběma instituty. Mám za to, že způsob, jakým je s oběma instituty procesně zacházeno, je pouhou technikálií, a zásadně by neměl determinovat, zda dlužníkovi bude poskytnuta ochrana vưči nepřiměřeně vysokému nároku na úrok z prodlení, či nikoli.

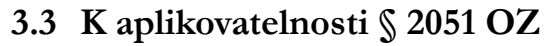

Lze tedy hovořit o mezeře $\mathrm{v}$ zákoně $\mathrm{v}$ situaci, kdy je ujednání shledáno jako platné (mravné), ale současně $z$ něj s přihlédnutím ke všem okolnostem nastalým až do okamžiku porušení vzniká nepřiměřený nárok (resp. úrok z prodlení v konkrétní již nepřiměřené výši)?

$83 \mathrm{~S}$ touto problematikou by přitom zdánlivě mohl souviset i \ 163 občanského soudního řádu. Mám ale za to, že uvedené ustanovení pro řešení otázek uvedených v tomto textu není podstatné. Ustanovení $\int 163$ občanského soudního řádu totiž směřuje na situace, kdy po vydání rozhodnutí odsuzujícího $\mathrm{k}$ plnění $\mathrm{v}$ budoucnu splatných dávek nebo plnění ve splátkách dojde $\mathrm{k}$ podstatné změně okolností, s nimiž při vydávání rozhodnutí nebyl soud obeznámen. Jedná se tak oproti nepřiměřenosti nároku o poněkud odlišnou kategorii, která představuje spíše snahu zákonodárce rozmělnit tvrdost závaznosti (resp. vykonatelnosti) rozhodnutí o budoucím plnění s přihlédnutím k tomu, že soud v takových případech musel vycházet z poměrů v době vydání rozhodnutí ( $\mathrm{tj}$. nemohl předvídat budoucí podstatnou změnu okolnostî).

84 Z četné judikatury srov. např. rozsudek NS ze dne 27. 1. 2011, sp. zn. 33 Cdo 2637/2008.

Je třeba ještě doplnit, že úroky z prodlení jako příslušenství pohledávky jsou ve vztahu k hlavní pohledávce nárokem akcesorickým ( $v$ řadě ohledů proto sdílí režim hlavní pohledávky - poukázat lze např. na promlčení, postoupení pohledávky či zajištění zástavním právem). K tomu srov. též ŠILHÁN, op. cit., s. 351. 
Mezera v zákoně představuje určitou nedokonalost právní úpravy, resp. protiplánovou neúplnost zákona. Rozlišujeme tzv. mezery pravé a mezery teleologické. V řešené problematice je přitom potřeba zkoumat existenci mezery posledně řečeného druhu. Jak podotýká Melzer, závěr o tom, že určitá otázka není právním řádem upravena, ještě nepostačuje pro konstatování mezery v zákoně. Vždy je třeba hledat protiplánovost takové neúplnosti. Je proto třeba zjišt’ovat, co je oním plánem zákonodárství. V tomto ohledu je zapotřebí zkoumat teleologické pozadí právního řádu (hodnotová rozhodnutí, právní principy). Legitimita dotváření práva je úzce spjata s principem hodnotové bezrozpornosti právního řádu. Důsledkem porušení tohoto principu je totiž bezdůvodná diferenciace. Při hledání mezery v zákoně lze proto použít toliko argumenty hodnotové. ${ }^{85}$

O otevřené mezeře $\mathrm{v}$ zákoně lze pak hovořit tehdy, pokud v něm absentuje určité pozitivní zákonné ustanovení. Teleologická mezera má podobu otevřené mezery, platí-li argumenty objektivně teleologického výkladu př́slušného ustanovení i pro skutkové stavy, které však nelze subsumovat pod jeho nejširší jazykový význam. V takovém př́padě tedy vzniká hodnotový rozpor, jenž se projevuje v tom, že z doslovného výkladu př́slušného ustanovení plyne pro jeden prrípad určitý následek, zatímco na druhý př́ípad ustanovení (ani v rozsahu nejširšího možného jazykového výkladu) nedopadá, a to za současného předpokladu, že se teleologie příslušného ustanovení vztahuje stejně na oba případy. ${ }^{86}$

Pokud se vrátíme ke smluvní pokutě a na chvíli pomineme existenci \2051 OZ, tak tento institut žádný ${ }^{87}$ jiný nástroj ochrany proti konkrétnímu nepřiměřenému nároku na smluvní pokutu již nemá. U úroků z prodlení sice určitá míra ochrany dlužníka existuje, nebot' podle \ 1805 odst. 2 OZ věřitel, který bez rozumného důvodu otálí s uplatněním práva na zaplacení dluhu tak, že úroky činí tolik co jistina, pozbývá právo požadovat další úroky. Tento korektiv ovšem není způsobilý př́ípadnou mezeru v zákoně uzavřít.

Předně je totiž otázkou, zda \1805 odst. 2 OZ nelze rovněž analogicky aplikovat i na smluvní pokutu sjednanou ve formě úroku z prodlení, či zda prrípadně bychom stejnou ochranu nemohli (a neměli) dovodit i v rámci moderace podle \2051 OZ (což by bylo patrně řešení mnohem elegantnějšîi). Jak ostatně bylo poukázáno výše, $v$ dobách účinnosti $\mathrm{OZO}$ byla liknavost věřitele s vymáháním dluhu podle tehdejší judikatury rovněž jedním z důvodů pro moderaci smluvní pokuty. Jakkoli je u smluvní pokuty

$85 \mathrm{~V}$ podrobnostech viz MELZER, Filip. Metodologie nalézánípráva: Úvod do právni argumentace. 2. vyd. Praha: C. H. Beck, 2011, s. 222-234. ISBN 978-80-7400-382-0.

86 Ibid., s. 230.

87 Bylo by však možné uvažovat o použití nejobecnějších korektivů nap̌r. podle $\int 6$ a $\int 8 \mathrm{OZ}$, nicméně $\mathrm{v}$ těchto př́padech již není kritériem nepřiměřenost konkrétně vzniklé sankce, nýbrž až nepoctivost jejího výkonu (uplatněnî) či zneužití takového práva. To jsou ovšem kritéria zcela odlišná, nebot' tato již (na rozdíl od kritéria nepřiměřenosti) nejsou měřítkem intenzity př́slušné sankce. Navíc je třeba zdůraznit, že nepřiměřenost nároku představuje objektivizované kritérium. Zkoumá-li se však kupř́ikladu, zda v dané věci došlo ke zjevnému zneužití práva, soustředí se při tomto přezkumu pozornost spíše na subjektivní stránku (tj. zda subjekt daného vztahu měl v úmyslu zneužít druhé strany). Naproti tomu, posouzení nároku jako nepřiměřeného existenci onoho zneužívajícího prvku nevyžaduje (byt' jeho přítomnost nevylučuje). 
konstantně judikováno ${ }^{88}$, že na nepřměřenost smluvní pokuty nelze usuzovat z její celkové výše, je-li důsledkem dlouhodobého prodlení dlužníka ${ }^{89}$, nelze v duchu shora popsaných závěrů pominout, že se jedná o stanovisko nutně vyplývající z dosavadního pojímání moderace smluvní pokuty jakožto moderace ujednání. V tomto pojetí totiž skutečnost, zda se stává sankce nepřiměřenou až důsledkem dlouhodobého prodlení dlužníka, není skutečností, která by byla povahově i časově spjata s obsahem smlouvy.

Dále pak argument, že u úroku je díky \1805 odst. 2 OZ alespoň nějaká (byt' omezená) míra ochrany proti nepřiměřenému nároku, a tudíž pro analogii není důvod, sám o sobě taktéž nemůže obstát. Ustanovení \1805 odst. 2 OZ totiž dopadá jen na určitou výseč situací, která se ani vzdáleně neblíží aplikačnímu rozsahu \2051 OZ. Příslušné ustanovení je tak způsobilé nanejvýš mezeru zúžit, nikoli ji zcela vyloučit. Lze tedy uzavřít, že \1805 odst. 2 OZ se z popsaných důvodů nejeví jako nástroj, který by měl vyplnit uvažovanou mezeru.

V neprospěch mezery v zákoně lze vyslovit i systematicky-formální argumenty. Podle nich učinil zákonodárce nastavením zákona mezi oběma instituty rozdíly, které je třeba respektovat. Dílčí rozdíly plynoucí ze zákona (především, že úrok z prodlení je příslušenstvím pohledávky, a tudíž se procesně uplatňuje jinak než smluvní pokuta) tak predeterminují, že každý z institutů má (ex lege) jiný účel. Kontrahenti si tak mohou svobodně zvolit, který z těchto dvou institutů zvolí, a to se všemi důsledky s tím spojenými. Jinými slovy, chtějí-li smluvní strany zařadit do obsahu smlouvy institut, který nepodléhá soudní moderaci, mohou si zvolit úroky z prodlení. Tyto argumenty ovšem nesdílím. Předně je třeba souhlasit se shora citovaným závěrem Melzera, že pro hledání (teleologické) mezery v zákoně je zapotřebí používat pouze argumenty hodnotové. Formálně-systematickými argumenty tudíž (ne)existenci mezery v zákoně zdůvodnit nelze. Nepřikláním se ani k závěru, že zákonné nastavení prŕíslušného institutu predeterminuje jeho účel. Ten je potřeba dovozovat ze smyslu právní úpravy jako celku, a především též z toho, jaký účel konkrétnímu institutu přivolí v právním jednání jeho subjekty (umožňuje-li jim zákon takovou možnost). ${ }^{90} \mathrm{O}$ odlišném účelu jednotlivých institutů (smluvních sankcî) přeci nesvědčí skutečnost, že zákon formálně odlišuje jejich povahu či rozdílně upravuje jejich fungování. I v takovém př́padě mohou nepochybně plnit stejný účel. Konečně, dovozuje-li se v doktríně (podle mého názoru správně) kogentnost \2051 OZ ${ }^{91}$, nelze přijmout ani závěr, podle kterého si strany mohou zvolit jiný institut (plnící stejné funkce), jež by jim umožnil se nezamýšleným následkům vyplývajícím z \2051 OZ vyhnout.

88 Srov. např. rozsudek NS ze dne 22. 9. 2006, sp. zn. 33 Odo 71/2006, či usnesení téhož soudu ze dne 27. 11. 2018, sp. zn. 20 Cdo 2841/2018.

89 Shodně LASÁK. In: HULMÁK, a kol., op. cit., s. 1290-1296.

$90 \mathrm{~K}$ tomu srov. shora citované závěry Petrova.

91 Srov. např. LASÁK. In: HULMÁK a kol., op. cit, s. 1290; nebo též ČERNÁ, Stanislava. In: ŠVESTKA, Jiří a kol. Občanský zákoník: komentár. Svazek V (J 1721 až 2520). 1. vyd. Praha: Wolters Kluwer, 2014, 1667 s. Shodně se prritom kogentní povaha dovozuje při obdobné úpravě i v Rakousku (viz HARRER, WAGNER. In: SCHWIMANN, KODEK a kol., op. cit., s. 843). 
Výše tak bylo detailně popsáno, že smluvní pokuta i smluvní úrok z prodlení v konkrétních případech mohou (ale samozřejmě též nemusî) plnit téže funkce a účel. Současné nastavení (a dispozitivita) zákona kontrahentům umožňuje, aby oba instituty využívali i do značné míry zaměnitelně. Teleologie moderace smluvní pokuty by se proto měla vztahovat i na smluvní úroky z prodlení. Nejsem si vědom důvodů, které by měly rozdílné zacházení s oběma instituty racionálně zdůvodnit. Dílčí rozdíly mezi oběma instituty lze považovat spíše za formální, nebot' se nejeví, že by měly mít vliv na funkce či účel toho kterého institutu. Pokud však zákon umožňuje sjednání konstrukčně (a funkčně) identického smluvního úroku z prodlení a smluvní pokuty pro př́pad prodlení, vedlo by prosazování aplikace \2051 OZ jen na jeden z těchto institutů k bezdůvodné diferenciaci mezi nimi.

Nelze nadto s ohledem na hodnotové pozadí občanského zákoníku přijmout závěr, že proti neprriměřenému nároku na úroky z prodlení nemá dlužník žádnou ochranu (zatímco proti stejné funkce plnící takřka totožné smluvní pokutě ve stejné výši sjednané ve formě úroků z prodlení dlužník ochrany požívá). Namístě ani není poskytovat takovou ochranu prostřednictvím dobrých mravů. ${ }^{92}$ Odhlédnu-li od skutečnosti, že se jedná o korektiv ultima ratio, není žádoucí, aby rozhodovací praxe dospívala ke dvěma rozdílným hranicím mravnosti. Není zkrátka korektní kupř́íkladu konstatovat, že ujednání o úroku z prodlení ve výši 0,6 \% denně z dlužné částky se v konkrétním př́padě (zejména pro výši takové sazby) příčí dobrým mravům, zatímco u smluvní pokuty sjednané v téže sazbě tento závěr neučinit, s poukazem na možnost aplikace \2051 OZ. Takové pojímání lze ovšem vysledovat z dosavadní rozhodovací praxe Nejvyššího soudu, podle které lze ze závěrů učiněných ohledně přiměřenosti smluvní pokuty vyjít i při posuzování „př́iměřenosti, a tudíž i souladu s dobrými mravy “ u výše sjednaných úroků. ${ }^{93}$ Uvedený závěr vede $\mathrm{k}$ tomu, že hranice nemravnosti u sjednaných úroků z prodlení se fakticky překrývá s hranicí nepřiměřenosti u smluvní pokuty. Tomuto závěru ostatně nasvědčuje i rozsudek velkého senátu Nejvyššího soudu ze dne 14. 10. 2009, sp. zn. 31 Cdo 2707/2007, který poukazuje na to, že zatímco v režimu občanského práva (kde moderace chyběla) lze nepřiměrenou smluvní pokutu posuzovat z hlediska neplatnosti pro rozpor s dobrými mravy, v režimu obchodního zákoníku existoval \301 zakotvující moderační oprávnění soudu, které je třeba mít za speciální k \39 tehdy účinného občanského zákoníku,

92 Tím ovšem není myšleno, že by úroky z prodlení měly být zbaveny i obsahové kontroly, prostřednictvím které se přezkoumává zejména mravnost ujednání. Tato kontrola by však měla zůstat kontrolou obsahovou. Mám za to, že vznikne-li z platného (mravného) ujednání nárok v nepřiměřené výši, je na místě jej z takového důvodu moderovat, nikoli částečně či zcela zneplatnit pro rozpor s dobrými mravy.

K problematice nadužívání dobrých mravů jako „obecného korektivu“ se fakticky vyjádřil i Nejvyšší soud v rozsudku ze dne 16. 3. 2021, sp. zn. 23 ICdo 56/2019, kde dovodil, že „zásah soudu do autonomie vủle stran pro rozpor s dobrými mravy bude predstavovat zásah výjimečný a vždy odivodnéný mimorádnými okolnostmi daného prípadu“" a současně, že ,korektiv dobrých mravu nevylučuje posouz̨ení, zdali na právni poméry stran nedopadaji primárnè jiná ustanoveni občanskébo zákoníku poskytujici právni ochranu jedné ze stran pred zneuživajicím jednáním drubé strany".

93 Srov. např. rozsudek NS ze dne 27. 3. 2008, sp. zn. 32 Odo 1651/2005. 
a tudíž lze takovou smluvní pokutu z důvodu nepřiměřené výše toliko moderovat. Mám za to, že takové pojímání nemravnosti je nekonzistentní a uvedené závěry je proto třeba (i v poměrech OZ) odmítnout.

Nad rámec výše uvedeného je třeba poznamenat, že rozdílným zacházením s oběma instituty dochází i $\mathrm{k}$ neodůvodněně rozdílné intenzitě zásahů do autonomie vůle stran ( $v$ prvém př́padě $\mathrm{k}$ neplatnosti celého ujednání, zatímco $\mathrm{v}$ druhém případě jen $\mathrm{k}$ moderaci). Pokud by soudy zvolily zdánlivě právně korektnější řešení a v takto srovnatelných př́padech ani neshledaly nemravnost ujednání o úroku z prodlení, pak by dlužníkovi neposkytly ochranu vůbec žádnou. Takové posuzování by však nebylo teleologicky koherentní (s přihlédnutím k existující ochraně dlužníka u smluvní pokuty a účelem, který má tato ochrana sledovat) a zjevně by zrcadlilo neudržitelnost stávající koncepce, která s moderací smluvních úroků z prodlení podle \2051 OZ nepočítá. Dospívám proto k závěru, že mezera $\mathrm{v}$ zákoně existuje, a to s poukazem na popsaný hodnotový rozpor právní úpravy, který zde v důsledku aplikace \2051 OZ jen na př́pady nepřiměřených smluvních pokut za současného nepostihování nepř̀měřených úroků z prodlení obdobným zpo̊sobem nepochybně vzniká.

Jako nástroj pro uzavření mezery se tak primárně nabízí (již nastíněná) analogická aplikace \2051 OZ (v pojetí moderace v tomto článku zastávaném). Mám za to, že se jedná o řešení veskrze rozumné (vedlo by k odstranění hodnotového rozporu totožným zacházením), které reflektuje ochranu dlužníka, na níž teleologicky cílí \2051 OZ, a současně jen minimalisticky zasahuje do autonomie vůle stran. V této souvislosti je třeba poznamenat, že ex offo zajišt'ovaná obsahová kontrola smlouvy (ujednání o smluvním úroku) by i za současné analogické aplikace \2051 OZ měla zůstat zachována. Moderace v režimu \2051 OZ (třebaže ji lze uskutečnit toliko k námitce dlužníka) by tak měla přistupovat k obligatorní (ex offo) obsahové kontrole a představuje tak vyšší standard ochrany. ${ }^{94}$

94 Vycházím totiž z toho, že úroveň ex offo ochrany poskytované prostřednictvím obsahové kontroly by měla (správně) být u obou institutů zcela totožná. V současnosti tomu tak v praxi zřejmě není, nebot' judikatura nahrazuje nedostatek moderace u úroků z prodlení tím, že uměle posouvá hranici mravnosti takových ujednání (tj. považuje za nemravná excesivní ujednání o smluvním úroku z prodlení, zatímco v zásadě srovnatelná ujednání o smluvní pokutě za nemravná nepovažuje, nýbrž je pouze moderuje). Takový prístup (stanovující dvojí hranici mravnosti) je však zcela nekonzistentní a působí poněkud zvláštně. Hranice posuzování mravnosti jednotlivých srovnatelných ujednání by se proto měly sjednotit. Je přitom třeba mít též na paměti, že překládané řešení se vztahuje zásadně k režimu podnikatelskému. Třebaže lze tak připustit, že navrácením posuzování hranic mravnosti „k normálu“ (tj. na v zásadě obdobnou hladinu, jaká je nyní dovozována u smluvní pokuty) může z krátkodobého hlediska dojít k mírnému zúžení rozsahu obsahové kontroly na úkor kontroly nárokové, nepovažuji tuto skutečnost za překážku uvedenému př́stupu. Zásahy do autonomie vůle by v podnikatelských vztazích měly být obzvláště odůvodněny (to přitom platí i pro moderaci, která je výjimečným institutem prolamujícím zásadu pacta sunt servanda). Samotná skutečnost, že by podnikatelé (dlužníci) museli teoreticky oproti dosavadnímu stavu (ex offo kontrole mravnosti) častěji namítat moderaci, ještě neznamená, že by došlo ke snížení míry jejich ochrany. Kontrola mravnosti (byt’ žrejmě fakticky v nepatrně omezenější míře) dlužníkům zůstává zachována. Současně skutečnost, že moderaci lze uskutečnit jen k námitce dlužníka, plně koresponduje s její výjimečnou povahou, s čímž se nutně pojí i motivace dlužníka (podnikatele), aby byl bdělý svých práv (v souladu se zásadou vigilantibus iura skeripta sunt). 
Pro soudní praxi by ovšem uvedené řešení mohlo být prakticky obtížně uchopitelné, a to především kvůli procesnímu zpơsobu uplatňování úroků. Problematická by v tomto ohledu mohla být skutečnost, že úroky lze soudním rozhodnutím přiznat i do budoucna. Za takové situace by nebylo žrejmé, jakým způsobem k moderaci v době rozhodování soudu prristoupit. Teoreticky by však soud mohl přiznat úroky jen do dne, kdy by kapitalizovaná výše úroků činila ještě přiměřenou částku, a smluvené úroky od tohoto dne již dále neprriznat (tj. nadále by nebyl dotčen nárok na úroky zákonné). ${ }^{95}$

Dále v úvahu připadá i teleologická redukce \2051 OZ pro případy smluvních pokut sjednaných ve formé úroků z prodlení. Takové pokuty by se (jen a pouze) z hlediska soudní moderace považovaly ve své podstatě za úroky a podléhaly by tak toliko kontrole obsahové. Popisovaný přístup by ovšem pro kontraktační praxi mohl být až př́iliš překvapivým a právní jistotu narušujícím, nebot' by došlo k vyloučení smluvních pokut sjednaných ve formě úroků (které praxe s oblibou využívá) z aplikačního dosahu \ 2051 OZ, ačkoli doposud o možnosti aplikace př́slušného ustanovení na jakékoli (nepřiměřené) smluvní pokuty nebylo sporu. Osobně se proto kloním spíše k prvně jmenovanému př́stupu.

\subsection{Exkurz do zahraničí}

Nasnadě je rovněž otázka, jakým zpơsobem se popisované problémy řeší v našemu právnímu řádu blízkých zahraničních úpravách. Alespoň v obecné rovině se tak budu zabývat př́stupem německým, rakouským a slovenským.

Předně je třeba uvést, že pojímání úroků z prodlení se může přirozeně v různých úpravách lišit. Na generalizované úrovni můžeme vysledovat tři různé (legislativní a doktrinálnî) prŕístupy pojímání úroků z prodlení.

Úrok z prodlení tak může být chápán jako čistě kompenzační nástroj, jímž se vyrovnává „bezdůvodné obohaceni" dlužníka spočívající v tom, že po určitou dobu (po dobu prodlenî) neoprávněně užíval věritelovy peněžní prostředky. Kompenzace se pak projevuje v tom, že úroky představují částečnou paušální náhradu škody způsobené věriteli prodlením dlužníka. To však nutně neznamená, že by náhradu další škody tento přístup vylučoval, či že by naopak vylučoval nárok na úrok z prodlení v situacích, kdy žádná škoda nevznikne. Věriteli se tak tímto způsobem mimo jiné dostává kompenzace i za prípadnou nehmotnou (byt' i právně irelevantnî) újmu, kterou by mohl pocit’ovat v důsledku toho, že mu jeho smluvní partner po dobu prodlení neoprávněně zadržoval peněžní prostředky. Úrok z prodlení tak v tomto pojetí reflektuje cenu peněz (jejich hodnotu v čase). ${ }^{96}$

95 Způsob jakým soud může moderaci úroků ve výroku rozhodnutí provést může být pochopitelně i jiný. Je otázkou, jaký by byl z procesního hlediska optimální. Domnívám se však, že konkrétní procesní postup není (resp. nemůže být) současně jedním z předpokladů moderace, nebot’ jeho prostřednictvím se moderace za splnění př́slušných podmínek (tj. obecně se vyžaduje existence nepřiměřeně vysokého nároku na úrok z prodlení a námitka dlužníka v řízení) toliko realizuje.

96 Obdobně ŠAFRÁNKOVÁ, op. cit. 
Toto pojetí čistě kompenzačních úroků dodnes zastává např́iklad rakouský občanský zákoník (dále jen „ABGB“). Ustanovení \1333 ABGB tak vychází z předpokladu, že věřiteli peněžitého dluhu vznikla škoda $\mathrm{v}$ důsledku prodlení dlužníka, přičemž tato škoda by měla být nahrazena zákonným úrokem. Př́slušná úprava vychází též z premisy, že držení kapitálu dává každému určité výhody. Ty mohou spočívat zejména v tom, že za daný kapitál může taková osoba získávat úroky, případně pokud by kapitál využila na splacení jiného dluhu, může tím úroky též ušetřit. V tom se projevuje hodnota peněz (kapitálu). Zákonný úrok z prodlení je tak zř́zen primárně k ochraně kapitálu. Podle rakouské doktríny vychází \1333 ABGB z myšlenek o „,bezdůvodném obohacení“ dlužníka, které se prostřednictvím úroků kompenzuje. Úrok z prodlení tak mimo jiné představuje paušalizovanou náhradu škody způsobené prodlením dlužníka. ${ }^{97}$

Rakousko proto nemá důvod zabývat se úvahami o excesivních smluvních úrocích z prodlení, když zákonné nastavení s takovými situacemi př́liš nepočítá. Citovaná komentářová literatura nezmiňuje možnost sjednání smluvní sazby úroku z prodlení. ${ }^{98}$ Přitom však platí, že v situacích, kdy věřiteli vznikne v důsledku prodlení škoda vyšší (která není kryta zákonnými úroky), může věřitel za určitých podmínek požadovat úroky vyšší než v zákonné výši. Podobně tomu ostatně bylo i v OZO, jak je popsáno shora. ${ }^{99}$

V Rakouském právu je tak nadále zachována silná vazba na náhradu škody a úrok z prodlení nepředstavuje primárně sankční nástroj, nýbrž nástroj kompenzační. Je třeba zdůraznit, že judikatura považuje excesivní ujednání o smluvním úroku z prodlení, které výrazně převyšuje obvyklé úroky z prodlení, za smluvní pokutu. ${ }^{100}$ Stojí prititom za zmínku, že vazba na náhradu škody existuje i u smluvní pokuty. V kontextu moderace smluvní pokuty (která je navíc podle rakouského práva možná i v podnikatelských vztazích) totiž výše škody hraje důležitou roli. Podobně jako tomu je v režimu \2051 OZ, i podle \1336 ABGB představuje skutečná výše škody dolní limit pro moderaci. Navíc doktrína dovozuje, že pokud porušení nezpůsobilo žádnou škodu, může se smluvní pokuta snížit ,až na nulu“. ${ }^{101}$ Tím fakticky může docházet k upřednostňování kompenzační funkce na úkor funkce sankční. Přesto však skutečná škoda není ve všech prípadech důležitá, nebot’ musí být vzata v úvahu jen je-li jistá, nebo ji lze snadno určit. Jinak je rozhodující potencionální škoda.

97 HARRER, WAGNER. In: SCHWIMANN, KODEK a kol., op. cit. s. 825-826.

98 Což ovšem neznamená, že by smluvní úprava výše úroku z prodlení byla rakouským právem zapovězena (navíc např. v oblasti směnek a šeků se výslovně počítá s možností sjednat si jinou úrokovou sazbu). Otázka excesivních úroků se ovšem s ohledem na jejich odlišné vnímání v rakouském právním řádu nejeví jako naléhavá.

99 Ibid., s. 827.

$100 \mathrm{~K}$ tomu srov. např. GRAF, Georg. In: KLETEČKA, Andreas, Martin SCHAUER a kol. ABGB-ON. Kommentar zum Allgemeinen bürgerlichen Gesetzbuch. Manz Verlag. Dostupné z: rdb.manz.at [právní informační systém]. \ 879, marg. č. 121, pozn. pod čarou č. 1084.

Srov. též rozhodnutí OGH ze dne 20. 7. 2016, sp. zn. 6 Ob 120/15p, rozhodnutí OGH ze dne 10. 5. 1984, sp. zn. 7 Ob 559/84, či rozhodnutí OGH ze dne 3. 12. 1953, sp. zn. OGH 1 Ob 828/53.

101 Ibid., s. 839-843. 
Lze tedy uzavrrít, že uvedené pojetí spíše (v obecné rovině) odpovídá v našich podmínkách historickému pojetí úroků z prodlení a smluvní pokuty v OZO, které však OZ již ve zcela totožné podobě nepřevzal. Koncepce úroků z prodlení v ABGB se od koncepce zvolené $\mathrm{OZ}$ v některých ohledech mírně odlišuje. ${ }^{102}$ Naproti tomu soudní moderace smluvní pokuty se od koncepce zvolené v OZ př́liš neliší a ze závěrů rakouské doktríny je proto možné vycházet. Smysl moderace tak bude v obou př́padech stejný.

$\mathrm{V}$ dalším možném (legislativním či doktrinálním) pojetí mohou být úroky z prodlení dále chápany jako převážně sankční nástroj. V tomto pojetí úroky představují peněžitou sankci za prodlení s peněžitou platbou. Jedná se tak v podstatě o speciální př́ípad smluvní pokuty. Kompenzační funkce je v tomto pojetí výrazně upozaděna a tím pádem chybí i jakákoli vazba na náhradu škody. ${ }^{103}$ Takové tendence lze vysledovat např́iklad v čl. 78 Vídeňské úmluvy o mezinárodní koupi zboží. Podle této úpravy vzniká právo na úroky nezávisle na vzniklé škodě. ${ }^{104}$ Článek 78 stojí v podstatě na koncepci nevyvratitelné domněnky, že v důsledku prodlení dlužníka nějaká újma věřiteli vždy vznikne. ${ }^{105}$ Navíc nárok na úroky z prodlení vzniká, aniž by byl současně jakkoli dotčen nárok věřitele na náhradu škody. Kompenzační funkce u takových úroků existuje pouze v latentní podobě, resp. v podobě subsidiární (právě s ohledem na zmíněný nezávislý vztah $\mathrm{k}$ náhradě škody).

Vedle toho existují i pojetí úroků z prodlení, které kombinují oba výše uvedené přístupy. Úroky z prodlení tak mohou mít (výrazné) funkce kompenzační i sankční. ${ }^{106}$ Takový př́istup byl zvolen v českém právu (ObchZ i OZ), ale též i v právu slovenském. V tomto ohledu stojí za zmínku odkázat i na navrhovanou úpravu slovenského nového občanského zákoníku, v němž si autoři návrhu jsou zřejmě vědomi řady v článku popisovaných problémů. Jednak poukazují na dlouhodobou problematiku zaměnitelnosti smluvních

$102 \mathrm{~V}$ ABGB je volen primárně kompenzační přístup. Naproti tomu OZ explicitně preferuje smluvenou sazbu úroků z prodlení a výrazněji zde (nad rámec kompenzačního pojetî) prostupuje i sankční pojetî úroků. Sankční složka je v rakouském pojímání (v komparaci s českým zákonným a judikatorním pojetím) nepatrně upozaděna na úkor složky kompenzační. O tom svědčí i doktrinální závěr, podle kterého jsou excesivní ujednání o úrocích z prodlení považována za smluvní pokutu.

103 Obdobně ŠAFRÁNKOVÁ, op. cit.

104 Srov. též např. FERRARI, Franco. In: Münchener Kommentar zum HGB. Band 5. \ 343-406 HGB, CISG. 4. vyd. C. H. Beck, 2018. CISG Art. 78 [Zinsen]. ISBN 978-3-406-67705-2. Dostupné z: Beck-online.de [právní informační systém].

105 Srov. např. ATAMER, Yesim M. In: KRÖLL, Stefan, Loukas A. MISTELIS a Maria del Pilar PERALES VISCASILLAS. UN Convention on Contracts for the International Sales of Goods (CISG). 2. vyd. München: C. H. Beck, 2020, CISG ARTICLE 78. ISBN 978-3-406-75911-6. Dostupné z: Beck-online.de [právní informační systém].

106 Rozdíl oproti rakouskému legislativnímu a doktrinálnímu pojetí se tak projevuje v tom, že sankční složka může výrazně převyšovat složku kompenzační, aniž by docházelo k překvalifikování takového ujednání na smluvní pokutu (tj. takové ujednání si nadále zachovává povahu úroku z prodlenî). (Pozn. Uvedené popisuje dosavadní stav poznání v české judikatuře, praxi a zčásti i doktríny. Dále v textu podrobněji naznačím i zde zmíněnou problematiku právní kvalifikace). 
pokut sjednaných ve formě odpovídající úrokům z prodlení se smluvními úroky z prodlení. Podle návrhu by se taková ujednání měla považovat za úroky z prodlení. Dále ale v navrhované úpravě též výslovně zakotvují právo soudu snížit neprriměřeně vysoké smluvní úroky z prodlení s tím, že se ustanovení o moderaci smluvní pokuty použijí přiměřeně. ${ }^{107}$ Takový přístup je však hned v několika ohledech zajímavý. Autoři návrhu se totiž nespokojili s ,pouhým“ odstraněním mezery v zákoně, k čemuž postačovala samotná konstrukce fikce smluvních úroků z prodlení pro př́ipady smluvních pokut sjednaných v takové formě. Třebaže již tímto by došlo k odstranění hodnotového rozporu, autoři návrhu se přesto rozhodli poskytnout dlužníkovi u nepřiměřených smluvních úroků z prodlení stejnou ochranu, jakou požívá u nepřiměřené smluvní pokuty. De lege ferenda lze českému zákonodárci inspiraci tímto přístupem nepochybně doporučit. ${ }^{108}$

Německý občanský zákoník (dále jen „BGB“) je primárně postaven na prústupu kompenzačním. I zde je tak východiskem teze, že úrok z prodlení představuje kompenzaci alespoň minimální presumované újmy, kterou věřitel v důsledku prodlení utrpěl. Smysl úroků tkví v tom, aby byl dlužník pod hrozbou povinnosti placení úroků zbaven pohnutek k vynucení si „povinné půjčky“ od věřitele tím, že nezaplatí svůj dluh. ${ }^{109}$ Ustanovení \288 BGB stanoví obecnou povinnost dlužníka platit úrok z prodlení a stanoví přitom zákonnou sazbu úroku (odst. 1,2). Pokud jde o vazbu na náhradu škody, tak podle odst. 4 není náhrada další škody vyloučena. Zákon sice výslovně nestanoví, že by se úroky na náhradu škody započítávaly, nicméně z kontextu (a formulace odst. 4) lze dovozovat, že se s kompenzací škody zpo̊sobené prodlením prostřednictvím úroků počítá. Povinnost platit úroky není odvislá od prokázání výše škody či přričinné souvislosti s prodlením. ${ }^{110}$ Podle odst. 3 může věřitel požadovat vyšší úrok z jiného právního důvodu. Tím může být podle doktríny i smluvená sazba úroků, která se připouští. ${ }^{111}$ Z komentářové literatury ovšem nelze vysledovat, že by úroky mohly plnit sankční funkci v takové míře, jako to připouští česká právní úprava. Kontrola výše sjednaných úroků je v BGB toliko obsahová. Je ovšem potřeba si uvědomit, že německá úprava obsahuje více nástrojů (resp. nástroje s širším aplikačním dosahem) než úprava česká. V tomto směru se prosadí

107 JURČOVÁ, Monika a kol. Jednotný systém nesplnenia a prostriedkov nápravy: Návrb koncepcie a pravidiel (ustanoveni) budúcej právnej úpravy. Praha: Leges, 2018, s. 177-178. ISBN 978-80-7502-327-8.

108 Je třeba ovšem zdůraznit, že slovenský návrh sekundárně obsahuje i alternativní přístup, podle kterého by nepřiměřeně vysoké smluvní úroky z prodlení byly (relativně) neplatné (JURČOVÁ a kol., op. cit., s. 75-76 a 177). Jakkoli tento článek nesměruje na problematiku excesivních smluvních úroků z prodlení ve smlouvách uzavíraných se spotřebiteli, lze pro zajímavost uvést, že slovenský návrh v těchto vztazích zvažuje absolutní neplatnost smluvních úroků z prodlení, které převyšují sazbu stanovenou nařízením vlády (Ibid., s. 75).

109 ERNST, Wolfgang. In: Münchener Kommentar zum BGB. 8. vyd. C. H. Beck, 2019, BGB, \ 288 Verzugszinsen und sonstiger Verzugsschaden, Rn. 1-5. ISBN 978-3-406-72600-2. Dostupné z: Beck-online.de [právní informační systém].

110 Ibid.

111 Srov. ERNST. In: MüKo BGB, op. cit., Rn. 40-47. 
v německém prostředí široce pojímaná ochrana prostřednictvím úpravy všeobecných obchodních podmínek (Allgemeine Geschäftsbedingungen). Na smluvní úrok z prodlení tak dopadá především úprava v \309 odst. 5 BGB, podle které smluvní úrok z prodlení nebude účinný $\mathrm{v}$ rozsahu, $\mathrm{v}$ němž převyšuje rozsah předvídatelné výše škody. Podle komentářové literatury tak s ohledem na současný velmi vysoký zákonný úrok neexistuje téměř žádný prostor pro dohodnutí vyššího úroku z prodlení. ${ }^{112}$ Je zjevné, že př́i posuzování „přriměřenosti“ úroků zaujímá v této úpravě klíčovou roli výše zákonné sazby. Přiměřenost smluvené sazby se tak odvijí hlavně od toho, do jaké míry se odchyluje od zákona. Do úvah o přměřenosti se ovšem prolíná i kompenzační aspekt úroků, nebot' je rozhodná i předvídatelná výše škody.

Německý obchodní zákoník (dále jen „HGB“) obsahuje speciální úpravu úroků z prodlení v \352. HGB přitom neobsahuje zvláštní nástroje pro řešení nepřiměřených smluvních úroků z prodlení. Ujednání ovšem zůstává podrobeno korektivům podle $\int 138$ BGB (dobré mravy a lichva). ${ }^{113}$ Význam absence speciální kontroly nicméně nelze přeceňovat. Hodnotové nastavení německého obchodního práva je totiž oproti českému právu rozdílné. Ustanovení \348 HGB totiž vylučuje možnost moderace smluvní pokuty v obchodních vztazích (tj. vylučuje \343 BGB). ${ }^{114}$

Lze proto uzavřít, že v německém právu nelze s ohledem na odlišné nastavení tamní právní úpravy v zákoně dovozovat mezeru z týchž důvodů jako v poměrech OZ. Ujednání o smluvní pokutě je v obchodních vztazích podrobeno stejným obsahovým korektivům jako ujednání o smluvním úroku z prodlení. Kontrola obsahu ujednání v občanskoprávních vztazích je potom BGB pojímána mnohem šířeji, než tomu je v OZ.

\section{Stručný exkurz do problematiky právní kvalifikace}

V návaznosti na shora řečené je třeba konstatovat, že v tomto článku řešeným problémům primárně předchází problematika právní kvalifikace. Je totiž otázkou, zda lze ujednání o smluvní pokutě sjednané ve formě odpovídající úrokům z prodlení ještě interpretovat jako ujednání o smluvní pokutě, či zda naopak není namístě je právně kvalifikovat jako ujednání o smluvním úroku. Tentýž problém mưže vzniknout i v opačné situaci, tedy zda v konkrétních věcech není třeba ujednání o smluvním úroku z prodlení právně kvalifikovat jako ujednání o smluvní pokutě. Právě právní kvalifikace by v určitých př́ipadech mohla řešit celou řadu v článku popisovaných problémů vznikajících v důsledku rozdílného zacházení s oběma instituty. Pokud bychom (po vzoru rakouské judikatury) dospěli k závěru, že sjednané smluvní úroky z prodlení s převažující sankční složkou je třeba právně kvalifikovat jako smluvní pokutu, shora popsaná mezera v zákoně

\footnotetext{
112 ERNST. In: MüKo BGB, op. cit., Rn. 40-47.

113 SCHMIDT, Karsten. In: MüKo HGB, op. cit., HGB \352 [Gesetzlicher Zinssatz], Rn. 10-12.

${ }^{114} \mathrm{~K}$ tomu srov. též GOTTWALD, Peter. In: MüKo BGB, op. cit., BGB, \ 343 Herabsetzung der Strafe, Rn. 3-4.
} 
by se tím zaplnila (odpadl by onen hodnotový problém spočívající v odlišném zacházení funkčně a účelově téměř totožných institutů).

Domnívám se přesto, že řešení v článku předkládané problematiky nebude v tuzemských podmínkách takto prosté. Vycházím z přesvědčení, že s přihlédnutím k výkladovým pravidlům v OZ nelze bez dalšího univerzálně přijmout tezi, že ujednání nazvané a konstruované jako smluvní úrok z prodlení je svojí podstatou smluvní pokutou. Jakkoli lze sice připustit, že $\mathrm{v}$ individuálních př́padech může nepochybně docházet $\mathrm{k}$ „,překvalifikování" takových ujednání soudem na smluvní pokutu, je potřeba k výkladu přistupovat velmi obezretně. Problematické se totiž v tomto duchu mohou jevit především situace, kdy vưle stran objektivně směřovala $\mathrm{k}$ volbě institutu úroků z prodlení. Oktrojoval-li by v takovém př́padě soud stranám (v rozporu s jejich jednoznačně projevenou i zamýšlenou vůlî) výklad, podle něhož by se teprve v soudním řízení dověděly, že si ve smlouvě ,ve skutečnosti“ nesjednaly úroky z prodlení, nýbrž smluvní pokutu, došlo by tím nepochybně k významnému (a především mám za to, že i racionálně neodůvodněnému) zásahu do jejich právní jistoty a smluvní svobody (resp. autonomie vưle).

Překvalifikování na smluvní pokutu přitom může přinášet i další problémy, které s moderací jinak nesouvisejí (nebo s ní souvisejí jen okrajově) - změna institutu může mít vliv na zajištění formou zástavního práva (srov. \1313 OZ), přiznání nároku věřiteli is účinkem do budoucna, či především může mít za následek náhlé vyloučení náhrady škody (srov. \2050 OZ). ${ }^{115}$ Tyto následky jsou proto nesporně větším zásahem do autonomie vưle stran, nežli v článku preferované řešení (aplikace \2051 OZ i na nepřiměřeně vysoký smluvní úrok z prodlenî).

Uvedený přístup pak navíc ve své podstatě zčásti popírá zákonodárcem zvolený dualismus těchto institutů s preferencí smluvní pokuty. Výše byla podrobně provedena funkční (či účelová) analýza obou institutů, která vedla k závěru o jejich extrémní podobnosti. Přesto však stranou toho byly popsány i zákonem konstruované rozdíly, které mají za následek, že se každý z těchto institutů v různých situacích chová poněkud odlišně. ${ }^{116}$ Tyto odlišnosti by sice neměly být významné z hlediska moderovatelnosti toho kterého institutu, avšak z hlediska právní kvalifikace je nelze pomíjet. Třebaže se jedná zásadně o dispozitivní ustanovení zákona, smluvní strany vedené úsporou transakčních nákladů mohly při volbě jednotlivých institutů zvažovat právě i tyto skutečnosti. Vnucená odlišná kvalifikace jimi zvoleného institutu by tak nikoli zanedbatelným způsobem měnila stranami zamýšlený obsah jejich závazkového vztahu.

V neposlední řadě pak tento př́stup zřejmě naráží i na samotné limity výkladu právních jednání, jak bylo naznačeno výše.

\footnotetext{
$115 \mathrm{~V}$ prrípadě prodlení s takto překvalifikovanou smluvní pokutou by pak následně mohl vznikat věřiteli i nárok na zákonný úrok z prodlení (zatímco pokud by kvalifikace směřovala k úrokům z prodlení, vznikal by nárok na další úroky jen tehdy, bylo-li by to zvláště ujednáno).

116 Viz výše uvedené odlišné chování u promlčení, zajištění zástavním právem, ve vztahu k náhradě škody atd.
} 
Problematika právní kvalifikace je ovšem natolik rozsáhlá, že by vydala na samostatný př́spěvek. V tomto článku se proto těmito otázkami podrobněji zabývat nebudu. Přesto však považuji za nutné upozornit, že tyto otázky mohou být pro zde řešenou problematiku klíčové.

$\mathrm{V}$ důsledku dosavadního pojímání judikatury i praxe, které v zásadě zachovává striktní dualismus smluvní pokuty a úroků z prodlení, se však do popředí dostávají v článku primárně řešené hodnotové problémy odlišného zacházení s oběma instituty. ${ }^{117}$

\section{Recentní judikatura NS k excesivním úrokům z prodlení}

Nejnovější rozhodovací praxe Nejvyššího soudu prozatím nenaznačuje žádné tendence k (byt' i pozvolnému) opouštění dualistického pojímání obou institutů. ${ }^{118}$ Posuzování excesivních úroků z prodlení pritom patrně v brzké budoucnosti žádných změn oproti stávajícímu pojetí nedozná. Nejvyšší soud v nedávném rozsudku ze dne 22. 9. 2020, sp. zn. 32 Cdo 1490/2019, rozhodoval patrně poprvé v režimu OZ o otázkách souvisejících s posuzováním excesivních smluvních úroků z prodlení. Rozhodnutí převážně zachovává dosavadní linii posuzování excesivně sjednaných smluvních úroků z prodlení prostřednictvím testu mravnosti ujednání. Určitým krokem kupredu nicméně je Nejvyšším soudem striktní odlišování pojmů, které se v praxi doposud (nesprávně) směšovaly a vyvolávaly řadu nevyřešených otázek. Nejvyšší soud v recentním rozhodnutí tak důkladně rozlišuje pojem nemravnosti sjednaného úroku z prodlení a jeho nepřiměřenosti. Stejně tak je z rozhodnutí patrné, že Nejvyšší soud striktně odlišuje i posuzování konkrétní výše úroku od posuzování sjednaného ujednání. To mưže být i výsledkem určité reflexe nad povahou moderace smluvní pokuty v OZ, která byla v dosavadní rozhodovací praxi pojímána do jisté míry nekonzistentně, přičemž doposud zastávané pojetí vyvolává řadu jen stěží vysvětlitelných otázek. ${ }^{119}$ Judikatorně doposud užívaný pojem neprriměřenosti (smluvní pokuty či úroku) má tak potenciálně do budoucna význam (pakliže dojde k již diskutované proměně pojímání moderace smluvní pokuty) jen jako kritérium ve smyslu \2051 OZ. Nepřiměřenost v tomto slova smyslu by tedy neměla být kritériem mravnosti ujednání, ale až jakési proporcionality konkrétně vzniklého nároku. Důsledné rozlišování pojmů lze proto hodnotit velmi pozitivně a citované rozhodnutí

117 Pokud bychom totiž dospěli k závěru, že (excesivnî) ujednání o smluvené výši úroků z prodlení nelze vždy bez dalšího kvalifikovat jako smluvní pokutu, nýbrž je třeba brát v potaz skutečnou vůli stran, právní kvalifikace by pak pochopitelně nepředstavovala komplexní řešení v článku popisovaných problémů (mezera by byla zaplněna jen pro případy ujednání, které takovou kvalifikaci umožňujî).

118 I excesivní úroky z prodlení jsou tak nadále kvalifikovány jako úroky z prodlení.

119 Jak bylo zevrubně popsáno shora, nevyjasněná je především povaha moderace smluvní pokuty jako moderace konkrétního nároku (nikoli konkrétního ujednání či sjednané sazby) a v dosavadní rozhodovací praxi se $\mathrm{v}$ tomto směru místy objevují rozpory. Sporný je též zejména časový okamžik, $\mathrm{k}$ němuž vztahovat posuzování nepřiměřenosti smluvní pokuty. S tím souvisí rovněž účinky moderace, které se podle posledně významného rozhodnutí velkého senátu NS nově vážou (ex tunc) k okamžiku sjednání, tedy k okamžiku, kdy ještě konkrétní nárok na smluvní pokutu a faktická nepřiměřenost smluvní pokuty vůbec nevznikla. 
v tomto směru může být jakýmsi „odrazovým můstkem“ pro v budoucnu vydávaná rozhodnutí přinášející nové (či vyjasňujícî) právní závěry.

Nejvyšší soud v citovaném rozhodnutí dále odkázal na dosavadní závěry rozhodovací praxe ve vztahu k posuzování nemravnosti ujednání o smluveném úroku z prodlení a zabýval se tím, zda se uvedené závěry uplatní i v poměrech OZ. V této souvislosti se vypořádal s \ 1972 OZ - zabýval se účelem tohoto ustanovení i důvodem, proč bylo do zákona zařazeno (vychází ze směrnice proti opožděným platbám). Učinil přitom klíčový závěr, že \1972 OZ nelze s ohledem na jeho účel (kterým zjevně není ochrana dlužníků) ani analogicky aplikovat na př́pady sjednání excesivně vysokého úroku z prodlení. Poté však dospívá k závěru, že smluvní volnost stran i v poměrech nové úpravy podléhá korektivu dobrých mravů, príčemž uzavírá, že ,tento korektiv tedy zjevně lže uplatnit i v prí-

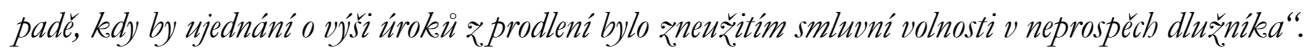

Co se týče samotného posouzení mravnosti zkoumaného ujednání, Nejvyšší soud zdůraznil, že toto závisí v každém individuálním prrípadě na úvaze soudu a je třeba jej posuzovat s přihlédnutím ke všem okolnostem, které ke sjednání takového úroku z prodlení vedly a jež existovaly v době uzavření smlouvy. Zároveň poznamenal, že proto nelze stanovit žádnou paušální „hraniční sazbu nemravnosti“ úroků z prodlení. Patrně klíčová pasáž rozhodnutí je ale následující: „Pouz̧e takové ujednáni o výsi úroku z prodlení výrazně se odchylujici od sazby úroku z prodleni stanovené nařizenim vlády zpuisobem, jenž by znamenal, že vzhledem ko okolnostem dané véci sjednaný úrok zpprodleni již, neslouži pouze k plnèní jeho funkcí, ale má zneuživajici (šikanózni) charakter, lze posoudit jako ujednáni rozporné s dobrými mravy. V'razná (mnohonásobná) odchylka sjednané výše smluvního úroku zprodleni od sazby stanovené narízenim vlády tedy mưže být signálem rozporu takového ujednáni s dobrými mravy, sama o sobè však. (bezposouzeni relevantnich okolnostíjejího sjednání) takový rozpor ještě neznamená."

Dále soud k předložené otázce dovolatele vymezuje okruh okolností, které je zapotřebí zkoumat. Zdůraznil přitom, že lze prrihlížet jen k okolnostem, které existovaly v době, kdy k tomuto ujednání došlo (tj. v době uzavření smlouvy), což plně koresponduje s dosavadním pojímáním tohoto př́stupu jako přezkumu obsahu smlouvy. ${ }^{120}$

120 Mezi tyto okolnosti řadí Nejvyšší soud zejména následující:

1) Důvody, které vedly ke sjednání výše úroku, a to ve vztahu k plnění jeho funkcí v konkrétní věci, přitom uvádí, že je třeba zkoumat [nap̌r. rizikovost obchodu ve vztahu $\mathrm{k}$ předchozímu chování dlužníka, rámcový rozsah očekávatelných škod na straně věritelé $\mathrm{v}$ př́ípadě prodlení dlužníka, předpoklad vývoje škod během času (tj. zda hrozí škoda jednorázová, anebo postupně se navyšujíîi), význam nesplaceného dluhu pro věritele, míru pravděpodobnosti vzniku předpokládaných škod].

2) Obsah posuzované smlouvy a skutečnost, zda současně s úroky z prodlení byla sjednána i jiná sankce za prodlení plnící obdobné funkce (například smluvní pokuta), či zda byla pohledávka zajištěna a jakým způsobem.

3) Obchodní zvyklosti stran a samotné okolnosti sjednávání.

4) Majetkové poměry účastníků $\mathrm{v}$ době uzavření smlouvy a prrípadně též vědomost o jejich očekávaných budoucích poměrech.

5) Povahu vztahu z hlediska jeho subjektů, když v podnikatelských vztazích je obecně vnímání hranice jednání, které již z pohledu dobrých mravů není akceptovatelné, odlišné od vztahů nepodnikatelských. 
Nejvyšší soud se ve svém rozhodnutí dále vypořádal i s kontroverzními nálezy Ústavního soudu ze dne 7. 5. 2009, sp. zn. I. ÚS 523/07, a ze dne 1. 7. 2010, sp. zn. I. ÚS 728/10, $\mathrm{v}$ nichž Ústavní soud dovodil neústavnost ujednání o úroku z prodlení ve výši $0,5 \%$ denně z dlužné částky, který podle něj byl „očividně (rovněž) za hranicí, kterou lze považovat podstatě a smyslu daného institutu úroku z prodlení za adekvátní“ (v druhém z jmenovaných rozhodnutí dokonce Ústavní soud výslovně uvedl, že je „protiústavní sjednání povinnosti zaplatit úrok z prodlení ve výši $0,5 \%$ denně, tj. 182,5\% ročněc). Takový závěr by přitom mohl implikovat, že krom neplatnosti ujednání pro rozpor s dobrými mravy, existuje ještě zvláštní kategorie „protiústavnosti“ ujednání o úroku z prodlení (resp. konkrétní sazby). Dílčí závěr Nejvyššího soudu (který mj. poukázal i na protichůdné nálezy Ústavního soudu v jiných věcech), že obecně nelze stanovit paušální „hraniční sazbu nemravnosti“ úroků z prodlení a je vždy zapotřebí přihlížet k individuálním okolnostem dané věci, je podle mého názoru třeba považovat za správný (jak ostatně plyne i ze závěrů v tomto př́spěvku prezentovaných).

V kontextu zmiňovaných kontroverzních rozhodnutí Ústavního soudu nelze opomenout ani v článku již rozebírané usnesení Nejvyššího soudu ze dne 1. 7. 2020, sp. zn. 20 Cdo 1655/2020, které nepovažuji za prŕiliš zdařilé. Z rozhodnutí je sice patrné, že se Nejvyšší soud snažil v co nejvyšší míře vyhovět oněm kontroverzním nálezům Ústavního soudu a takovému postupu lze do značné míry porozumět. Vedle toho ovšem závěry, k nimž Nejvyšší soud v př́slušném rozhodnutí dovodil a jaké úvahy jej k nim vedly, vyzdvihovat bohužel nezasluhují.

Nejvyšší soud totiž aproboval právní posouzení odvolacího soudu spočivajícího v tom, že se má úrok z prodlení podrobovat „testu prriměřenosti“, přičemž se má vycházet z kapitalizované výše nároku, zkoumat konkrétní okolnosti vedoucí ke sjednání úroku a jeho výši, ale především též důvody nesplnění a dopady na osobu povinného. Jinými slovy v rozporu se svojí dosavadní praxí Nejvyšší soud (inspirován Ústavním soudem) pro účely exekučního řízení založil „test přiměřenosti“ konkrétního nároku. Nikterak přitom nezdůvodnil, proč má být konkrétní nárok podroben testu přiměřenosti až v řízení exekučním. Pro takto flagrantní zásah do nároku přiznaného pravomocným a vykonatelným rozhodnutím nalézacího soudu musí ovšem svědčit přesvědčivé argumenty. Tím spíše si lze klást legitimní otázku, proč není (nemůže být) nárok na smluvní úrok z prodlení podroben obdobnému testu přiměřenosti již v řízení nalézacím, kde by i s ohledem na právní jistotu účastníků a jejich legitimní očekávání bylo bezesporu žádoucí takové zásahy provádět a nesečkávat s nimi až do řízení exekučního.

Nejvyšší soud v této souvislosti v rozhodnutí konstatuje, že si je vědom toho, že ujednání o výši úroku z prodlení lze podle dosavadní rozhodovací praxe posuzovat $z$ hlediska souladu výše s dobrými mravy jen jako platné či neplatné s tím, že namísto neplatného ujednání o výši úroku z prodlení nastupuje sazba zákonná, přitom ale konstatuje, že zmiňovaná judikatura není pro projednávanou věc relevantní, když tato se týkala ř́izení 
nalézacího a nemožnosti moderace úroků v nalézacím řízení, a nikoli řízení o výkonu rozhodnutí, kde je v rámci částečného zastavení prováděného výkonu rozhodnutí možné dospět $\mathrm{k}$ závěru, že přiznané př́slušenství pohledávky již odporuje právním zásadám demokratického státu. Na jedné straně si tak Nejvyšší soud je zjevně vědom neudržitelnosti současného stavu, kdy proti nepřiměřeným úrokům nelze v souladu s dosavadní judikaturou nijak postupovat, avšak na straně druhé se od těchto závěrů neodvrací, považuje je nadále za použitelné a vzniklý problém se pokouší napravit kostrbatým a argumentačně nepodloženým řešením až v řízení exekučním, a to za cenu výraznějšího zásahu do legitimního očekávání a právní jistoty účastníků řízení.

Není pak také zřejmé - což sice lze vytýkat především Ústavnímu soudu, jehož konstrukci Nejvyšší soud převzal - jak s nepřiměřeným úrokem z prodlení souvisí „zásady demokratického právního státu“, které soudy využívají pro zdůvodnění svých rozhodnutí. Skutečně je státní zrrízení natolik relevantní pro posouzení, zda lze věřiteli přiznat úrok z prodlení v excesivní výši? S tím pak souvisí i oběma soudy používaný pojem „protiústavnosti“ úroků z prodlení, který snad působí jako zvláštní kategorie excesu. Jaký je potom vztah úroků nepřiměřených, nemravných a protiústavních? Používá-li Nejvyšší soud pojem ústavnosti a přiměřenosti zaměnitelně, jedná se potom o pojmy významově shodné?

Konečně lze poukázat též na skutečnost, že finální závěr soudů tendoval k modifikaci sazby úroků z prodlení, přestože jim daný stav patrně umožňoval moderovat kapitalizovanou výši úroků tak, že by exekuci částečně zastavil pro úroky ode dne, kdy by kapitalizovaná výše převyšovala výši přiměřenou. Ačkoli tedy předmětem přezkumu byla přiměřenost kapitalizované výše úroku (tj. konkrétní nárok), výsledná úprava se v rozporu s tímto posouzením týká jen samotné sazby (tj. ujednánî).

Z popsaných důvodů tak nelze toto rozhodnutí hodnotit pozitivně. Jeho význam však nakonec může být snížen v důsledku rozhodnutí Občanskoprávního a obchodního kolegia Nejvyššího soudu, které jej neschválilo k publikaci do sbírky.

\section{Závěr}

Závěrem lze konstatovat, že aplikační praxe by neměla mezi smluvními úroky z prodlení a smluvní pokutou sjednanou v téže formě činit umělé rozdíly, které nekorespondují se současným (ani historickým) pojímáním obou institutů. Teleologie \2051 OZ vyžaduje, aby s oběma instituty (i s ohledem na jejich zaměnitelné využívání ve smluvní praxi a mnohdy se shodující funkce) bylo zacházeno podobně. Toho lze primárně docílit prostřednictvím změny právní kvalifikace. Domnívám se nicméně, že tato cesta (právní kvalifikace) patrně nenabídne univerzálně použitelné řešení aplikovatelné na všechny případy excesivních úroků $z$ prodlení (především na ty případy, kdy by př́ekvalifikování vedlo $\mathrm{k}$ př́ḱkému rozporu s úmyslem stran a projevenou vůlî). Vyhovět teleologii 
\2051 OZ a docílit tak podobného zacházení lze pak dále bud’to pomocí teleologické redukce \2051 OZ tak, že toto ustanovení nebude aplikováno na př́pady smluvních pokut sjednaných ve formě odpovídající smluvním úrokům z prodlení, anebo pomocí analogické aplikace \2051 OZ i na př́pady smluvních úroků z prodlení. Z důvodů výše vyložených jsem pak přesvědčen, že $\mathrm{v}$ zákoně skutečně existuje mezera (spočívající v neodůvodnitelném hodnotovém rozporu), kterou je v souladu s požadavkem bezrozpornosti právního řádu zapotřebí uzavřít.

Historická komparace ukázala, jakým způsobem byly v minulosti oba instituty vnímány a jaký byl historický účel moderace. Úvahy o způsobu řešení nepřiměřených úroků z prodlení se po dlouhou dobu př́liš nevyvijely, nebot' právní úprava (a žrejmě ani praxe) s existencí excesivních smluvních úroků bud'to př́liš nepočítala, anebo pod vlivem socialistických kodexů (jejich pozůstatků) bylo preferováno jakékoli excesy penalizovat neplatností. Ostatně, i pojímání neplatnosti doznalo v souvislosti s přijetím OZ významných změn a preference moderace namísto neplatnosti by nepochybně s touto proměnou korespondovala.

Vedle toho komparace s rakouským a německým právem automaticky přenositelné závěry pro účely posuzování nepřiměřených úroků z prodlení nenabízí, a to z důvodu mírně odlišného pojímání úroků v těchto právních řádech. ${ }^{121}$ Jiná situace je ovšem u moderace smluvní pokuty, když inspirace těmito úpravami zjevně ovlivnila podobu \301 ObchZ a posléze i \2051 OZ. V tomto směru je proto žádoucí závěry tuzemské právní vědy se zahraniční doktrínou konfrontovat a případně se jimi inspirovat. Komparace se slovenským právem (resp. zamýšleným lex ferenda) ukázala, že v textu popisované problémy skutečně existují a je zapotřebí je nějakým způsobem pro futuro vyřešit. Zajímavá je mimo jiné i pro způsob řešení těchto problémů, který byl ve slovenském návrhu zvolen.

Pokud jde o test mravnosti ujednání u úroku z prodlení, tak tento zůstane i nadále zachován. Pozitivně lze v tomto směru hodnotit, že Nejvyšší soud konečně jednoznačně vymezil kritéria (byt’ neuzavřeným výčtem), která je při posuzování mravnosti ujednání o smluvních úrocích zkoumat. Domnívám se, že rozhodovací praxe by v budoucnu měla vyloučit z kontroly obsahu ujednání o smluvním úroku z prodlení možnost aplikace \576 a 577 OZ. Jejich aplikace na ujednání o smluvním úroku, které se příčí dobrým mravům, se totiž nejeví jako žádoucí, nebot' by mohla v konečném důsledku vést k nežádoucímu arbitrárnímu testování hranic práva.

Samotným závěrem je třeba připomenout, že v článku demonstrovaná úskalí posuzování excesivních smluvních úroků z prodlení ke svému řešení předpokládají pojímání moderace smluvní pokuty jako moderace nároku (tj. nikoli obsahové kontroly ujednánî). Prezentovaný př́istup by pravděpodobně vedl ke změně spočívající v jistém (byt'

121 Inspirativně však může působit především tamější pojímání právní kvalifikace některých ujednání o smluvních úrocích z prodlení jako smluvní pokuty. 
zřejmě nikoli výrazném) posunutí hranice toho, co je dnešní judikaturou považováno za ujednání rozporné s dobrými mravy. Lze se domnívat, že tato hranice bude reflektovat posuzování mravnosti ujednání o smluvní pokutě. S prrihlédnutím ke skutečnosti, že dobré mravy jsou zásadně korektivem ultima ratio, se přikláním k názoru, že by se jednalo o změnu správným směrem. Ostatně, dosavadní judikaturou zastávaný př́stup o dvojí hranici mravnosti u úroků z prodlení a smluvní pokuty ${ }^{122}$ je jen stěží argumentačně obhajitelný.

Rozhodovací praxe přitom v současnosti čelí velké výzvě - v rigidním a setrvačném prostředí justice je zapotřebí změnit dosavadní pojímání moderace smluvní pokuty tak, aby odpovídalo požadavkům \2051 OZ a došlo tak k odstranění logických rozporů a problémů, které jsou po dlouhá léta s moderací spojena, a na něž doktrína nejednou poukazovala. Vyjasní-li se však povaha moderace smluvní pokuty, prijidou nepochybně časem do praxe i otázky palčivější, právě ve vztahu ke smluvnímu úroku z prodlení (zejména z důvodu jejich konstrukční a funkční blízkosti). Jsem přitom přesvědčen, že právě správně koncepční uchopení moderace smluvní pokuty může otevřít cestu pro nalezení optimálního způsobu řešení nepřiměřených úroků z prodlení.

122 Tj. že ujednání o úrocích z prodlení jsou považována za rozporná s dobrými mravy, zatímco konstrukčně totožná ujednání o smluvní pokutě jsou považovaná toliko za nepřiměřená a následně jsou moderována. 